UC-NRLF "Win В 3 ㄹ 리 


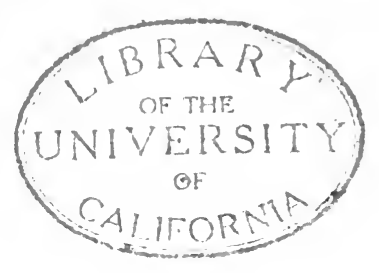


Hoin th की

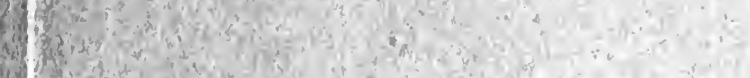

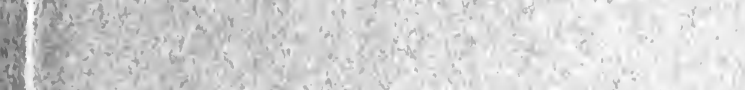




Digitized by the Internet Archive in 2008 with funding from Microsoft Corporation 
3,3

, , ,

, , , , , , 3

, , , , , ,

3,3

30

$\because 3,1$

, : , , 3,

33,

313 3,

3

$3,3,3$

,3, , , ,

,3, ?, , ,

3,3 


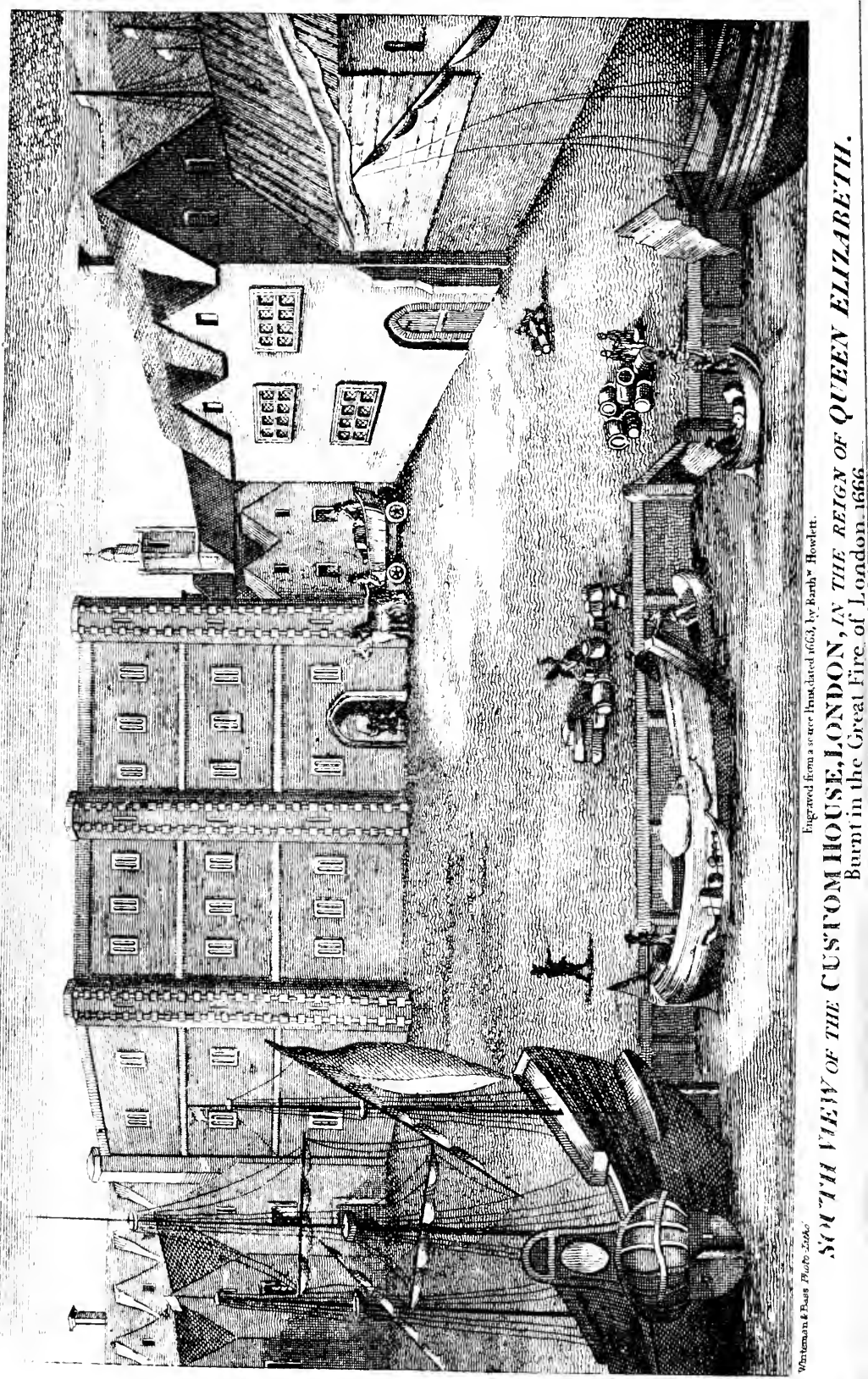




\title{
CHRONICLES
}

\author{
OF THE
}

\section{CUSTOMS DEPARTMENT}

\author{
BY \\ W. D. CHESTER
}

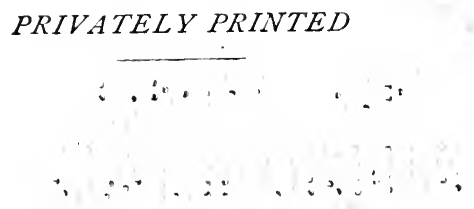

\section{LONDON}

I 885

All Rights Reseried 


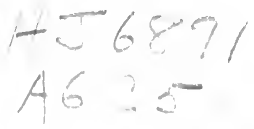

LONDON :

R. Clay, Sons, and Taylor,

BREAD STREET HILL.

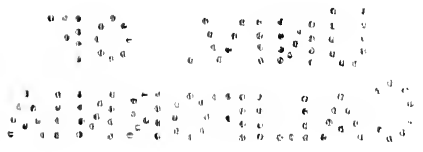




\section{P R E F A C E.}

FOR several centuries moneys arising from Custurns duties have formed a large and valuable addition to the imperial revenue of this country.

In the collection of the Customs many curious events have occurred which, perchance, are little known to the present generation. The existing records of the London Custom House possess a national importance, and in the following pages will be found a brief history of the origin and development of a system, which, from small proportions has grown to such an extent, that the Exchequer at the present time derives a sum exceeding twentythree millions annually from the Customs.

In this department, even in the present and the last century, interesting details have been noted which exemplify the difficulties experienced in collecting these imposts, and the efforts made by the mer- 
cantile community in all ages to evade them-these, and other matters bearing on the subject, are given, not only for the information of present readers, but to prevent facts being buried in oblivion.

For many of the particulars contained in Chapters I. and II., I am indebted to the researches made by the late Mr. James Oldham, who collected interesting details which are annexed to the first report of the commissioners of Customs to the Treasury, in the year I857. I have consulted Haydon's Dictionary of Dignities, biographical and old authorities, from which many of my notes have been gleaned. The strictly official memoranda, relating to events since $\mathrm{I} 84 \mathrm{I}$, are from my own personal experience ; in the main points they are fairly accurate. The illustrations given are facsimiles of prints of buildings which can be relied on as accurate. Stowe makes no mention in his History of London of any Custom House in his time. A diligent search in the British Museum and elsewhere has failed to substantiate whether any and what Custom Houses existed prior to the reign of Elizabeth.

As all the buildings up to I 8 I4, with the chief archives, were destroyed by fire, I have experienced much difficulty in gathering details of our past service, 
and this will account for the brevity of my "Chronicles." I have endeavoured not to overburden them with extraneous matter, and thereby increase the size of the book, being anxious to give only such particulars as I consider acceptable to the general reader.

Doubtless there is much which has escaped my notice-any information that may reach me I shall be glad to embody in a further edition should the verdict of the public be favourable to another issue.

$$
\text { W. D. C. }
$$

Cusiom House, London,

February, 1885. 



\title{
C O N T E N T S.
}

\begin{abstract}
CHAPTER I.
PAGE

HISTORICAL . . . . . . . . . . . . . . . . . . . 3
\end{abstract}

CHAPTER II.

FORMER MODES OF COLLECTING THE CUSTOMS REVENUE I3

CHAPTER III.

NOTABLE FRAUDS ON THE REVENUE . . . . . . 3 I

CHAPTER IV.

CleVER EVASIONS OF THE LAW ......... . . 4 I

CHAPTER V.

TRICKS OF SMUGGLERS . . . . . . . . . . . 49 


\section{CHAPTER VI.}

MEN OF NOTE CONNECTED WITH THE CUSTOMS DE-

PAGE PARTMENT . . . . . . . . . . . . 67

CHAPTER VII.

PRESENT AND FORMER BUILDINGS IN LONDON . . . 75

CHAPTER VIII. DEPARTMENTAI, CURIOSITIES . . . . . . . . . 85

RÉSUMÉ . . . . . . . . . . . . . . . . . 97

APPENDIX A. . . . . . . . . . . . . 103 
CHRONICLES

\author{
OF \\ THE CUSTOMS.
}





\title{
CHAPTER I.
}

\author{
HISTORICAL.
}

There is little doubt that the Romans imposed on the inhabitants of Britain duties on goods imported into and exported from this country, and that after their departure these imposts were continued.

No trace, however, exists of the actual rates imposed until the reign of Ethelred, A.D. 979, when, by his "Witanagemote" held at Wantage, it was enacted that "every smaller boat arriving at Billingsgate should pay for toll or custom one halfpenny, a larger boat with sails one penny, a keel or hulk four pennies, a vessel with wood one piece of wood, a boat with fish coming to the bridge one halfpenny or a penny according to the size.

The men of Rouen, in Normandy, that came with wine and large fish, and those of Flanders and 
Ponthieu, and others from Normandy and France, were wont to open their wares and free them from toll. The Emperor's men (Germans of the Steelyard) who came with their ships might buy in their ships, but they were not to forestall the market from the burghers of London. They were to pay toll, and at Christmas two grey cloths and one brown one, ten pounds of pepper, five pairs of men's gloves, and two vessels of vinegar, and as many at Easter. The term, "open their goods and free them from toll," appears by a note in McPherson's Annals of Commerce to mean, "showed their goods and cleared the duties."

These dues, it is presumed, were paid to the officers of the reigning monarch, but until we come to the Records of the Exchequer, temp. Henry II., it is impossible to see what was the value of the imposts on goods imported or exported. In the twenty-third year, however, of the reign of that monarch, we find that the ferm of the Queen's Hithe, the then port of London, was accounted for at $£_{3} 6$, which according to modern ideas is a very insignificant amount. And subsequently in the eighth year of Richard I. the fines and dismes of merchants paid unto the exchequer by the Chamberlain of London for tin and other mercatures amounted to $£ 379$ is. 6d. only, and the fines for leave to import woad into England and sell it there to $£ 966 s .8 d$. 
In IIgS the judges itinerant held pleas of the Crown in which "inquisition was to be made of the Keepers of the Sea Ports, if they have received anything which they have not paid, and if they have received any bribe for withholding the King's rights, and if any person has received anything who has not been duly appointed for the same purpose. Inquiry is to be made, if all appear, who such person is, and what is his name, for it is by these and other vexations whether justly or unjustly that all England has been reduced to poverty from sea to sea."

From this extract it is evident that considerable duties were levied on goods imported, and that there existed persons appointed to collect the same, otherwise the influence of judges would not have been enlisted to inquire into the king's losses which had been so greatly increased by reason of smuggling and the connivance at fraud.

King John in 1205 appears to have claimed onefifteenth part of all merchandise imported, together with such other Customs as might be laid according to his pleasure: and although the barons at Runnymede secured a charter from him which cost him nothing, pecuniarily, he obtained a good equivalent from these imposts.

Our early sovereigns benefited largely on the 
importation of wines-certainly from the time of Richard I.

The king's butler was an important personage; he was privileged to select from the best sorts of all wines imported, and took away such as he desired for his master's benefit, paying only the small sum of 20 s. per tun, for freight.

Some idea may be formed of the consumption of foreign wine in this country in the reign of Edward I. from the fact, that from Martinmas 1272 to Michaelmas I 273, the duty on this article collected at London, Southampton, Portsmouth, and Sandwich, was on no less a quantity than 8,846 tuns, and this did not include dues paid on small importations of less than twenty tuns under the term prisage-and as smuggling then was carried on at other places on the coast, doubtless wine was introduced without payment of any duty whatever. These obscure facts would seem to point to the conclusion that in Edward I.'s. time wine was the common beverage of the country. These wines would appear to have come from France, Spain, Italy and Germany.

The commerce of this country in the time of Edward I. must have been carried on to a greater extent than is generally supposed from the shores of the Mediterranean and North Africa and Spain, for the following articles were then subject to Customs duties, 
viz., almonds, rice, pepper, ginger, white cinnamon, incense, quicksilver, vermilion, cummin seed, sugar, liquorice, pimentum, rosin, sulphur, raisins, figs, cloves, nutmegs, mace, cubebs, saffron, silk, \&c. (See Thompson's History and Antiquities of Boston, I 856.) At this date the sea route was not much known and America had not been discovered; these goods must therefore have reached this country by the Mediterranean, as it is not at all probable they came overland through Europe. The fruits and raisins would have had their origin in Spain and the Levant, their present homes of production. The spices from Ceylon or other Indian fields of growth, and sulphur from Sicily, and quicksilver no doubt from Spanish mines. From this enumeration it is not difficult to see that the sea trade to this country had been largely developed, and when we look back to the imperfect knowledge of navigation possessed in 1285 , we cannot fail to wonder at the boldness of our merchant speculators in sending their ships on what was a difficult and hazardous system of long sea voyages-for in the then state of Europe as regards direct land routes we can hardly suppose these articles came to this country except in ships. Turkey and Egypt, with the ports in northwest Africa, must have been busy emporiums for the shipment of products which can only be grown in warm latitudes. From India, Ceylon, and Batavia, we 
now receive such articles as cloves and nutmegs, from which we may conclude that at the time mentioned they came from those parts : in fact with all the modern appliances of acclimatising they are not sent to us from any other place, and to the present day Sicily is our great field for procuring sulphur.

It would seem that Free Trade is not a modern innovation, for in the Parliament held at Stamford, 2oth August, I309, it was directed that duties upon wines, broad cloths and " avoirdupois" should cease, in order that it might be ascertained what advantages would result to the king (Edward II.) and his people thereby, and collectors were ordered to stay the collection of Customs until further orders.

A subsequent parliamentary writ however stated as follows :- " And it being evident that no advantage had ensued either to the King or his people, the prices of such merchandizes not having become lower after the cessation of the duties, the collectors are commanded to resume the collection of the duties and to answer the receipt to the King's butler." These duties were recommenced on 2oth August, r3 3 o. So that Free Trade had been tried for twelve months and was declared a failure.

The French rôles of king Henry V., a hundred years later, I 4 I 3 to I422, throw a light on the commercial history of that reign. The principal exports of Spain 
at this time were figs, raisins, wine, oil, skins, soap, and quicksilver, which were shipped to England in exchange for our wools, then superior to those of every other country. Safe-conducts for vessels trading between Spain and England are therefore frequently found in the French rôles. The Flemings were then the most skilful weavers in Europe, but being dependent upon England for wool, a brisk trade was carried on between England and Flanders. At this time too commerce between this country and Portugal and Brittany was active and friendly. 'The Genoese in their great "carracks" came to England laden with cloths of gold, black pepper, oil, and cotton. The Venetians and Florentines brought spices, sweet wines, articles de luxe and foreign drugs. (See Appendix to Forty-fourth Annual Report of the Deputy Keeper of the Public Records, IS83.) 
(5) 


\section{CHAPTER II.}

\section{THE FORMER MODE OF COLLECTING THE CUSTOMS REVENUE.}





\section{CHAPTER II.}

THE FORMER MODE OF COLLECTING THE CUSTOMS REVENUE.

AN ancient method of collecting the "king's revenues" was by farming them out to private individuals. There are records extant showing that the system was in force at the time of Henry II. and continued through the Commonwealth to the date of the Union with Scotland, 1707.

These farmers appear to have had a high time of it in all ages, and made ample fortunes. Under Queen Elizabeth, Sir T. Smith, a Secretary of State, farmed the Customs revenue, first for $\mathcal{E}_{4} 4,000$ per annum, but subsequently had to give as much as $£ 5^{\circ}, 000$ a year for the privilege. With the increase of commerce the bids seem to have increased also, for in 1688 these dues were let for nearly $£ 600,000$. 
Farmers of the revenue were not always Englishmen. The merchants of Lucca farmed the duties on wool and skins in the reign of Edward I., whilst the merchants of Frescobaldi farmed the king's Customs, they being creditors of the Crown, and paid their own debts and export duties, taking good care of themselves; for, according to Rymer, they were unmitigated smugglers, and were accused by that monarch of robbing his exchequer to the extent of $\mathcal{E}$ roo,000 sterling.

Genoese and Florentines figured as farmers as early as 1282, and for $£ 20$ a day the Bardi of Florence farmed the entire Customs revenue in 1329. The sovereign and his government must have been quite at the mercy of these foreign usurers. They were the only people in those days sufficiently wealthy to make advances to an English king who, to obtain his supplies, was compelled to comply with the terms of such capitalists.

In our own day something very similar is taking place in Turkey and in Egypt, and if in the year ${ }_{23} 8_{4}$ the historian is writing up the financial account of the manner in which the present Khedive's wants were supplied, the names of Englishmen and some Frenchmen will be mentioned as the farmers to whom was allotted the duty of collecting the Egyptian imposts on behalf of some foreign bondholders who 
were large creditors of the ruler of Egypt in the year 1884 .

As time wore on the exactions and vexations of farmers became so oppressive and intolerable that importers and financiers combined to put an end to their monopolies, and in $167 \mathrm{r}$ the Customs dues were taken out of farm and their collection was transferred to Boards of Commissioners in London, Edinburgh, and Dublin, since amalgamated ${ }^{1}$ in one, although the farming system continued on a small scale until a later date, probably until the Scottish Union in 1707 .

But to revert. When the Customs dues were put in farm, the farmers employed their own officers in the collection. The Crown, however, appears to have appointed certain officials to watch over its interests and supervise the extent of such collections, especially in the export and coasting business, in which the farmers later on had no part. We find mention made of the following officers at various dates, viz., searchers, weigher, and finder, temp. Richard II.,

1 I find, however, in the Public Record Office Report for the year I881, Appendix I., p. 607, mention of an order in Council, 28 June, I66r, ratifying and confirming articles between H. M.'s Commissioners of Customs and the factors residing in Dover for the composition trade to be settled in the port of Dover, Dover Road, and the Downs; so that Commissioners existed prior to the date supposed. 
customers or collectors, controller, and aulnager or measurer of cloth. In $167 \mathrm{I}$ all these offices became patent offices under the Crown: such government nominees appointed their deputies, who again selected persons to assist. In every grade these parties owed their employment to political or local influences, and the patentees frequently retained their offices as sinecures.

Residence in the place to which patentees were appointed was not compulsory; for example, the collector for Hull in 1774 was located in London, his deputy at Glasgow, and his chief searcher at Dorchester. In this year, when Liverpool was subordinate to Chester, the deputy-controller died; it became necessary therefore to appoint a successor. The patent controller of Chester, to whom the right of nomination belonged, was in India, and the government had to issue a deputation in his stead. At this date it was found that out of sixty-three patent offices in the Customs revenue collection, all but ten were sinecures.

Principals and deputies received but nominal salaries from the Crown. They were remunerated by fees they imposed on merchants, in most cases arbitrary in amount, and far beyond what was commensurate for the services performed. This system became an intolerable abuse, and the source 
of continual disputes between inporters and the patentees and their subordinates.

Some idea of the extent to which this extortionate system prevailed and the large incomes accumulated, may be gathered from the fact that, on the abolition of fees to Customs officers in $583 \mathrm{I}$, there were in the Long Room in London patent officers styled cocketwriters, whose average fees were estimated at $£ \mathrm{I}, 000$ per annum each, although their acknowledged salaries were only $£ 60$; and a junior clerk, with a nominal salary of but only $£$ roo, received $£ 800$ per annum as remuneration for his loss of fees, calculated at the rate of one-third of his actual receipts. If this was the income of a junior clerk of the patentee it may be surmised that his chief had a very lucrative and comfortable sinecure.

A good joke is told about the patent clerks in the Long Room. These parties had been called upon to furnish a statement of their emoluments from the receipt of fees. They imagined that the government had an intention of imposing a tax thereon, and all but two individuals very much understated their profits. To their surprise and disgust the Treasury notified their decision to abolish their offices and compensate them according to the returns they had furnished, which was accordingly done. They were, however, permitted to retain seats in the Room and 
pursue their business as private agents to the mercantile community, irrespective of the Crown. These gentlemen, twelve in number, were designated the twelve apostles, who, like Matthew, remained at the seat of Custom.

Not one of the race now survives; the last connecting link between the old and existing system was Mr. Oxenford, who died in December, 1883 , in the one hundredth year of his age, having enjoyed his compensating pension from the Government for upwards of fifty-two years. He had long ceased to occupy his seat in the Room, but his business was carried on by his son. The pension paid in this case was altogether $£ \mathrm{r} 0,400$, and the period it was enjoyed is the longest on record. He was a most genial and well-cultivated gentleman, bright and brilliant to the last, and when he had attained the usual span of human life of seventy-one years, journeyed to Germany and acquired a full knowledge of the language of that country. The name of Oxenford is well-known in theatrical circles, the celebrated playwright and adapter, John Oxenford, was a brother of our friend, and his grandsons are not unknown to fame as writers of some of the best and purest of our drawing-room ballads.

The old method of keeping accounts of Customs duties paid to the Crown was by means of parchment 
rolls handed by the customer or collector and the controller to the receivers of the Revenue in the government Exchequer. And until about sixty or seventy years since the following method was adopted:

The place of receipt was in the office of the Tellers of the Exchequer. The parchment roll, on which was recorded the amount paid in, was thrown down a pipe into the Tally Court, where a tally was struck.

This Tally Court took its name from the French word tailler, to cut. The tally was a piece of wood on which was written on both sidesan acquittance for moneys received. The wood was about two or three inches in width and three and a half feet in length. It was then cloven asunder down the centre by a deputy-chamberlain; one part, called the stock, was delivered to the person who paid or lent the money to the government, the other portion, called the "counter stock," was retained in the office to be kept until called for, when the two parts were joined together.

This method was deemed sufficient to prevent fraud, as any disagreement in uniting the two pieces would be at once discovered. In addition to the writing, notches were cut in the sticks to indicate the sums paid; a large notch stood for a thousand pounds, a smaller one for one hundred pounds, a still smaller 
notch for ten pounds, and so on for single pounds, shillings, or pence.

The destruction of the Houses of Parliament in I 839 is said to have been occasioned by the overheating of flues caused by burning some of these old Exchequer tallies.

It is difficult in the present day to realise this antiquated system of keeping accounts of the large sums that found their way to the Exchequer, and if a similar method prevailed with bankers in remote times it would have been a curious sight to see depositors carrying away their tally sticks, which possibly may have been used to protect the wayfarer in defending himself against footpads and highwaymen. In case of fire the first care of our ancestors must have been to preserve their tally sticks from destruction.

It may reasonably be assumed that a system of receipt and discharge which was in favour with the government Exchequer was followed by the banking houses, but this is a point for the antiquary to settle. Some of these tally sticks are preserved in the Customs Museum in Thames Street, and to the curious in such matters are worthy of being inspected.

For the greater ease and encouragement of importers it appears that in the reign of Charles I. a part of the duties imposed on certain articles imported was not 
required to be paid down on entry, but security by bond was to be given for the remainder at certain periods of time. These bonds for linens, silks, and other articles extended over twelve months, for wines nine months, and tobacco eighteen months, whilst a discount of Io per cent. was allowed for cash payments at the time of import. These duties were, however, refunded if the goods were exported; in the case of linen and tobacco to the full extent, and for other articles one-half. I 2 Car. 2, c. 24.

The practice of giving credit foreshadowed the introduction of the present warehousing or bonding system, which was first partially introduced in 1700 , and has since been extended generally to articles liable to duty.

An examination of the Patent Rolls of the reign of Charles I. between 1625 and 1632 shows that in consideration of large sums advanced to the king, his revenue from Customs imports was hypothecated to the great financiers of the time. The names of the following persons frequently occur in these patents, viz., Sir Paul Pindar, Sir John Wolstenholme, Abraham Dawes, and John Jacob, who had liens on these duties. They appear to have figured almost yearly as creditors for advances to the Crown. On March 7 th, I631, the king granted a demise to the above, for a year, of the general Customs on imports and exports at $\mathcal{E}_{\mathrm{r} 50,000}$ a year, 
with power to retain $£ 30,000$ by them already advanced, and $£^{26,500}$ disbursed for the king's use.

The king would appear to have borrowed very extensively from his subjects, and on every possible occasion pledged the moneys coming to him directly and indirectly from the duties on goods imported and exported. His jewels and plate, and, indeed, the household gold and silver, seem to have been always in and out of pawn; the rolls contain some curious items showing the straits to which royalty was subjected in those days.

Amongst the many lenders to the Crown, and others who were recompensed out of the Customs imposts the following names appear in the records of that reign in addition to the leading financiers already noted :

1626. I7 Feb.-Sir George Hay, Lord Chancellor of Scotland, had a lease for twenty-four years of Customs subsidies and imposts on smaults, saffers, and pot ashes imported or exported.

1627. I7 Sep.-J. Harrison and E. Fenn had a lease for nine years of impositions on sugar imported, except the Customs subsidies payable before 6th January, at the rate of $£ 2000$ a year.

1627. 28 June.-Lady Barbara Villiers had a demise 
of the Customs subsidies on gold and silver thread for twenty-one years.

1628. I7 May.-Earl of Montgomery granted a lease for twenty-one years of the "overslipt" Customs on woollen stufis.

1629. 20 June.-A grant to Wm. Murray, Groom of the Bedchamber, Ios. on every aume of "Deale" or Rhenish wine imported.

1629. 30 July.-John de la Barre, merchant, a grant of $£ 5,700$ in consideration of the same amount disbursed by him for the king's service, out of the Customs and duties on goods by him exported or imported.

1630. I7 Feb.-Sir Dudley Diggis paid $£_{2,625}$ in consideration of his surrender of an annuity of $£ 500$ out of the "silk farm" held by assignment from the Earl of Salisbury.

r630. 24 May.-Grant to Sir William Russell, Bart., of the imposts on silks, cambrics, and lawns, for the reimbursement of moneys expended in marine affairs, in case of failure of assignments and bonds from the farmers of the great Customs, amounting to $£ 45,000$, and a further sum of $£$ 10,367 upon the collection of silks.

I63 r. 6 July. - Philip Burlamachi, of London, merchant, a demise for twenty-one years, from Christmas 
I635, of the poundage, \&c., on sugars imported into England and Wales for the sum of $\mathcal{E}^{1}$ 1,945, reserving a yearly rent of $\mathcal{E}^{2,000}$.

I63I. 3 I Oct.-Lord Baltimore granted a pension of $\mathcal{E} \mathrm{i}, 000$ a year out of the imposition of wines for twenty-one years, in consideration of his surrender of former letters patent, with a discharge of $£_{2,000}$ imprested unto him for increase of the subsidy on raw silks.

I632. 24 May.-Katherine, Duchess of Buckingham, demise for fifteen years in consideration of $£ 2,000$ of the Customs subsidies and imposts in Ireland at the yearly rent of $\mathcal{I I I}, 050 .^{\circ}$

Several of the persons named in patents, under which they held liens on Customs duties, appear to have held offices as collectors, comptrollers, and surveyors of Customs, which appointments they insisted on to enable them to watch over their own interests and secure the payment of the imposts due.

I find that Sir Paul Pindar was collector at Chester, and his co-partner, Abraham Dawes, filled the office of collector in London and, in addition, was norninated Clerk of the Rolls in England and Wales for thirty-one years, from I628. John Jacob, another partner, was also receiver of duties on tobacco, I629. A. Dawes was also surveyor of Customs at all the outports in 
1627 , as well as collector of subsidies of tonnage and poundage.

From the aforegoing it is evident that in the reign of Charles I. farmers, patentees, and grantees absorbed the whole of the king's Customs, and that the imposts on goods imported and exported were always pledged for advances made to the sovereign ; and that these were not sufficient to meet the urgent demands of the State is evidenced by the frequent pawning of the Crown jewels and plate, and that the condition of the monarch was always very impecunious.

Coffee and tea, which at the present date yield a large portion of the Customs revenues, are not mentioned in the book of rates 1660 . In that year an excise duty was imposed on beverages made from those articles. Fourpence a gallon was charged on coffee and $8 d$. a gallon on chocolate made and sold, to be paid by the maker.

So scarce was tea in the year 1664 that it is asserted the East India Company, wishing to make a present to the king of some rarities, could only procure 2 lbs. 2 ozs. of tea, for which they paid 40s. a pound.

One hundred years later the quantity of tea brought into this country by illicit methods was estimated at seven millions of pounds annually. The East India Company then enjoyed a monopoly in the article, and 
their sales between 1773 and 1792 were under six millions of pounds.

At this period brandy, on which a duty of $7 \mathrm{~s}$. a gallon was imposed, could be purchased at the coast for 3 s. a gallon.

Smuggling was then a lucrative pursuit, for we find in a parliamentary report of $\mathrm{r}_{7} 83$, on the question of illicit importation, that the revenue was defrauded to the extent of two million pounds sterling annually.

For the edification of political economists the following facts are given :

In 1797 the laws of the Customs filled six large folio volumes, and between that date and 18 I $_{5}, 600$ more Customs acts were added. The whole number of such acts passed prior to the accession of George III. was 800 , to which were added $\mathrm{r}, 300$ more during the first fifty-three years of his reign, and as there was no index to such laws the present generation may well wonder how the mercantile community must have been puzzled to find out what was required of them to fulfil the law, and to what extent Customs officers were taxed to check the entries submitted to them by importers.

The labour and trials of patience endured in paying duty to the Customs revenue must have been immensc, since, in the year 1787 , there were on the tariff no less than 1,425 articles subject to impost, 
composed of principal articles and subdivisions of the same. The revenue therefrom amounted to about six millions sterling. There were in 1882 only twelve articles subject to impost duties, realizing a revenue of nineteen millions.

Space will not suffice to show the several rates of duty to which imported goods were subjected in bygone years, but it may be mentioned that in 1797 no less than $\mathbf{I}, 200$ articles were liable, whilst at the present date (1884) the following are the only goods chargeable with duty on importation, viz., beer, cards, chicory, coffee, cocoa, dried fruit, malt, plate, spirits, tea, tobacco, and wine.

In 1876 the Customs laws were consolidated and comprised 290 sections, which embrace everything connected with this department for the United Kingdom.

The tariff, first greatly reduced by Pitt in $1787,{ }^{1}$ was further diminished in succeeding years, notably by Sir Robert Peel in 1842 and 1845 . In the latter year $45^{\circ}$ articles were removed from the list, and since then a continuous and decided progress has been made in the same direction by various governments.

The first important attempt to consolidate the Customs laws was made in the $\mathrm{I} 2$ Charles II., when

1 In consequence of a treaty with France. 
the act styled the "Book of Rates" was passed. An additional "Book" was issued in the reign of George I., but as the new duties came to be added and old ones modified, complications were so multiplied that the system was most bewildering to importers, as may be seen by the example given in Appendix A. This state of things was, however, greatly remedied by Pitt in 1787 , when he introduced his three thousand resolutions in parliament.

But although the complexity heretofore existing in the department was greatly ameliorated, difficulties still remained in the mode of appropriating the duties when paid into the Exchequer; they had to be placed to the credit of various funds, such as the South Sea Company, mortgages for annuities, and lotteries. Ultimately they were all paid to the "Consolidated Fund." 
CHAPTER III.

NOTABLE FRAUDS ON THE REVENUE. 
4 


\section{CHAPTER III.}

NOTABLE FRAUDS ON THE REVENUE.

Prior to the year I84I, the duty on silk piece goods was very high, from IIs. to $30 s$. per pound according to description. The places in London where such goods were examined by Customs officers were styled "silk floors" and were very jealously guarded, the greatest precautions being taken to secure to the revenue its dues on every ounce of the article.

Landing waiters engaged in assessing these duties were selected for their sharpness and general acumen, and these officers were supervised by surveyors who regulated the tares of the cases, paper, \&c., used in packing the silks. The trade was chiefly confined to French goods and the imposts were considerable, the duty on larger packages frequently reaching as much as $£$ r 5 o.

The books in which the accounts of the examination were entered by the landing waiter, had blue paper covers, the leaves of every page bore an im- 
pressed stamp of a ship, a fac-simile of which is given on the cover of this work, were sewn together with black thread, and the ends brought to the front cover and sealed with a Customs seal before delivery to the officer engaged in taking the account. It was, therefore, supposed that leaves could not be abstracted and others substituted without detection, when the accounts were subjected to examination by the "Jerquer" or examiner. It was the business of the surveyor to examine these books and notify by his signature the tare allowed and the weight of silk to be charged with duty, and this was deemed the safeguard against fraud.

About the year 1840 r $84 \mathrm{r}$, some large importers made overtures to the landing waiters to defraud the revenue by the insertion in the books of a less weight of silk than was contained in the packages. The officers could have easily done so, but their difficulty was to secure the signature of their superior officer to any falsified accounts.

A fraud was, however, effected by these means. A page from an unused book, of which there were always plenty at hand, was brought into play, a leaf was taken out, the account was written thereon with falsified weights and tares, and the signature of the surveyor was traced on the falsified account by holding the original on the new sheet against a 
window at the house of the importer. It then became a question how to introduce in the genuine book a false leaf without its being noticed.

The fraudulent officer was equal to the occasion. He represented to a well-known seal engraver that, as a responsible officer of Customs, he had had the misfortune to lose his seal, and requested to be supplied with a new die like the impression he produced; having obtained this the bonâ fide book was cut asunder, the required leaf was interpolated and the thread resealed, thereby defeating all chance of detection: the diminished duties on the quantity of silk recorded were paid. This artifice went on for a considerable time, the landing waiter receiving from the fraudulent importer large sums for his complicity, frequently more in one transaction than the salary he was paid by the Crown.

By an accident it was surmised that frauds of some description were being carried on. Officers were known to be living in a style far beyond their official incomes, they became involved in speculations and bills, and I O U's were discovered, with some very compromising correspondence.

As soon as inquiries were set on foot a panic took place amongst these rogues, and the cleverest of the gang, who had obtained the false seal, determined to be first in the field and turned approver against his colleagues in the conspiracy. The result was a 
general suspension of many officers, who were charged with fraud and dismissed. Many fled the country and died in penury, some languished for years in prison here, and others were reduced to beggary. The arch conspirator eked out a miserable existence in a position very inferior to that he had held under the Crown.

These disclosures ramified into other but less important breaches of trust, and for two years, down to $\mathrm{r} 843$, many men who had figured as most respectable officers were dismissed, or reduced for malpractices in which they had been concerned. In some cases they were the victims of a vicious system that had grown up of receiving from merchants gifts for small attempts of fraud on the revenue, or conniving at malpractices which assisted the merchant in his importations to the detriment of the Crown.

The chief firms of silk importers concerned in the above transactions did not escape; they were exchequred for some thousands of pounds. At that date any attempt to defraud the revenue was not regarded as a criminal offence in the mercantile world, but it was a bitter lesson to them. In later years one man, noted for his position and political influence in the city of London, received many overtures to stand and represent the city in Parliament, but ne dared not appear on the hustings whilst the recollections of these doings was in the minds of his contemporaries. $\mathrm{He}$ is now dead, and 
the misdeeds of his firm are not known to the present generation. One other firm was broken up, and the partner who had been instrumental in the frauds died heart-broken in France; he had made many offers to the government in part payment of the fines imposed on him, which were rejected.

On reviewing these cases it is impossible to exculpate the officers for their great breach of trust, but it must be admitted that the temptation put before them by the importers was almost too great to withstand, when by a stroke of the pen they obtained in five minutes an amount of money larger than they received in twelve months, relying on the presumption that there was no fear of detection.

In the present day there does not exist the same incentive to fraud, the duties are so low that similar deceptions are not worth the risk; and beyond that the system of check and surveillance render such artifices almost impossible.

Another scheme adopted by a well-known firm in the silk trade was ingenious and for a time successful, but in the end was discovered through the information of the approver already alluded to.

This firm imported silks in cases of a peculiar size, and marked with their private signs. Having plenty of packages of this description they forwarded to one of the quays in Thomas Street a case filled with paper and straw, a counterpart in every particular of a

D 2 
package of silks they had imported and which was then lying at the examination floor awaiting the scrutiny of the Customs officers. A cart bearing the dummy package was drawn up on the quay under the delivery loop-hole of the floor. By a concerted plan the parties interested in the venture raised a cry of a fight in the street below, the officers rushed to a window to see the fun of the planned mêlée, and whilst so absorbed the full case of silks was lowered into the cart, and the dummy was lifted to the floor and took its place. The superior officers were subsequently called upon to examine the dummy, and certifying that it was a returned case and no duties being due it was passed out of charge. The result of this trick was the saving of a considerable sum in respect to the case they had carted away. The ruse was successfully carried out on several occasions, and would never have been known but for the evidence of the informer.

Accidental and insignificant events have frequently been the means of discovering frauds on the Customs revenue, of which the following is an interesting specimen.

A vessel from Holland was discharging at one of the quays near the Custom House a cargo of presumed oil-cake; an officer was placed on board to watch the unlading. Two or three wagon loads had left, and at mid-day the labourers ceased work for 
dinner, when an officer on the quay paid a friendly visit to his colleague on the vessel. Some joking took place between them, and in a "quasi" sparring match one took up a piece of oilcake from the deck and threw it into his opponent's mouth. The effect was to set him sneezing and choking, and the utterance of very uncomplimentary words at the attempt to poison him. An explanation soon satisfied them that this oilcake was not genuine, and upon examination it was discovered that the whole cargo was snuff made up into the form and shape of "cattle food." The ruse on the part of the importer was at once discovered. The laden vans were pursued and detained whilst on their journey to some snuff mills in the Essex Marshes. The cargo was of course confiscated, and the parties concerned prosecuted.

As the Customs Service is, and has been, recruited from all ranks of the general public, it must naturally follow that human failings in the cause of rectitude have from time to time prevailed, and the administration of an oath to be true and faithful in the discharge of their duties as servants of the Crown has been no safeguard against improper practices.

Happily, however, we are able to chronicle but the following severe instance of an official combination of a smuggler with a Customs officer, as distinguished from their collusive acts with importers. Not very many years since a tide surveyor at a northern port 
who had earned frequent praise and rewards for his intelligence in the detection of smuggling transactions had the tables turned against him by those he had been the means of sending to gaol.

This man had for a long time found money for the purchase of tobacco in Holland, and, through an agent, he freighted small sloops with the article bound for the said port. Occasionally he would allow the cargoes to be run, but not unfrequently he would seize his own tobacco and the ship also, and cause the crews to be sent to gaol; in such cases he got paid a reward of so much per pound for the tobacco captured, head-money for each seaman convicted and a share of the proceeds of the vessel when sold. The victims were at the time unaware of the duplicity of their employer, and as the men were well rewarded for the runs which were successfully made, they were always ready to join in these ventures. It happened, however, that a disagreement took place about the division of the spoils, and recriminations occurred. The gang rounded on the tide surveyor; he was suspended, charged, and dismissed the service.

As a further illustration of the lenient view taken by the British public of smuggling as an offence against the laws and morality of the country, it must be noted that the authorities of the borough where these malpractices occurred gave to the officer on his dismissal the lucrative post of harbour-master. 
CHAPTER IV.

CLEVER EVASIONS OF THE CUSTOMS LAWS. 



\section{CHAPTER IV.}

CLEVER EVASIONS OF THE CUSTOMS LAWS.

Mr. Charles Barry, who figured about forty years since as a Customs agent and general merchant, was gifted with a wonderful mind for business. $\mathrm{He}$ was a shrewd observer, and ready on the instant to pursue an advantage where there was a loophole in the law. To the cute financers of the present day he would have been a most valuable ally.

Revenue enactments were Charles Barry's study, and that his quick perception served him well, the three following instances will show.

By a convention entered into between England and the United States, it was agreed that higher or other duties should not be imposed on the exportation of any article to those States than such as were payable on the exportation of like articles to any other foreign country. 
Under an act of 59 Geo. 3 , export duties had been collected on woollens shipped to the United States. In the year $1825 \mathrm{Mr}$. Barry discovered that export duties had not been levied on the like goods shipped to China and Japan, and he contended that duties should not have been levied on the exports to America. The duty was discontinued in 1829, and Mr. Barry claimed repayment of the amounts levied to that date.

The principles of the claim were admitted by the government, a mixed commission under a convention between the two countries was formed in 1853 for a settlement. It however, did not meet, for Charles Barry agreed to a compromise by the payment by the government of $£ 40,000$, of which sum he received for his trouble about $£ \mathrm{r} 8,000$. This settlement took place in 1855 .

Mr. Charles Barry scored heavily against the government on another occasion.

By the provisions of the act 5 Vic. c. 147 a duty was imposed on grain imported into the United Kingdom from any British possession in North America or elsewhere, out of Europe-but was silent as regards British possessions in Europe, the framers of the law being under an impression that there were no such possessions. Mr. Barry thought differently, and by his subsequent actions 
taught the Parliamentary draughtsman a geographical lesson.

$\mathrm{He}$, and others associated with him in his venture, freighted a large amount of tonnage in the Black Sea with corn, which they had carried to Malta, whence it was reshipped and brought into the port of Gloucester. Barry claimed the admission of the grain free of duty as coming from a British possession in Europe, which he contended Malta most certainly was, and that the law did not allow duty to be collected on corn brought therefrom.

The Customs refused to deliver the goods free, and Barry paid the duties under protest, and commenced an action against the government.

It was speedily discovered that Barry had an unanswerable case, and the Treasury wisely submitted to his terms of compromise by a payment of $£ 47,000$. This claim was paid by the government in the year 1848 .

The largest and heaviest fight with the government conducted by Mr. Barry was on the following case.

By Article II. of a treaty of commerce, dated July 2oth 18 r $_{5}$, between this country and the United States, it was provided that no higher duties should be imposed upon the importation into the United Kingdom 
of articles the produce of America, than were levied on articles the produce of any foreign country, thereby placing the United States on the same footing as the most favoured nation.

By a tariff act (6 of Wm. 4), which took effect from August 1836 , a duty of one penny per quarter was imposed on rice in the husk from the west coast of Africa, the duty on the like article from America under a previous act being $2 s$. $6 d$. per bushel; so that whilst the African rice only paid a penny, the United States rice had to pay 2.0s. per quarter. In the year $\mathrm{r}_{3} 8$ this anomaly was discovered, and under the advice of Mr. C. Barry, importers of American rice tendered duty at the lower rate to the Customs officials in London and Liverpool, which was refused. Payment of the higher sums claimed was made under protest, the government at first insisting on the larger due as their undoubted right.

Mr. Barry on behalf of his clients, the importers, commenced an action at law to try the question. The validity of his claim was, however, so evident, that Sir Robert Peel, then in power, was forced to admit the justice of the demand, and consented to refund the over payments made between the year 1836 and $184 \mathrm{I}$, when the law was altered to remove all doubts on the subject. 
The settlement was not finally carried out until the year I 846 , when the government refunded the sum of $£ 94,653$.

Mr. Barry deserved considerable credit for the way in which he overcame the government. What share he received for his pains is not known, but his tact and shrewd knowledge of the weak points of Customs laws, enabled him to make the exchequer. in these three instances disgorge not less than $£$ i 81,653 .

It is well known that tobacco very readily absorbs moisture from its surrounding atmosphere, and in damp localities rapidly increases in weight.

A manufacturer engaged in a large way of business, acquainted with this fact, hit upon the following plan for defrauding the revenue :-

$\mathrm{He}$ established in one of the Channel Islands a series of drying rooms, artificially heated to a temperature of $90^{\circ}$. Large quantities of leaf tobacco were despatched to his depôt. The article, after being subjected to a drying process, was closely packed in barrels, with this effect-that a parcel weighing, say one hundred pounds, was reduced after drying to about sixty pounds. The tobacco was then introduced into England and duty paid on the actual weight of the article in its dry state.

When taken to his factory the tobacco was un- 
packed and, being exposed to the atmosphere, soon regained its normal weight; so that he had secured without payment of duty the difference between the weight of the tobacco in its dry state as imported and that which it regained after absorption of the moisture, and thereby realised a handsome profit.

This evasion went on for a considerable time to the great detriment of the revenue. The subterfuge was at length brought to the notice of the government, who took steps for checkmating the practice. The law was altered by imposing a duty on tobacco according to the quantity of moisture contained therein at the time of importation on its ascertained normal state, the rate being higher in proportion to its dryness. This had the desired effect, for the manufacturer found that his drying process was no longer available to secure any gain of duty thereby. 
CHAPTER V.

TRICKS OF SMUGGLERS. 



\section{CHAPTER V.}

\section{TRICKS OF SMUGGLERS.}

Officials engaged in the collection of dues, rates, tolls, and taxes, have been always viewed with dislike and disfavour by the parties who have to pay. Even the collector at a turnpike gate was regarded as a nuisance and little short of an extortioner, but Customs officers and excisemen have from time immemorial been targets for the shafts of satire and the victims of opprobrium generally. The persistence with which they always claim for their employers the uttermost farthing, with callous indifference to all remonstrance, has been met in all ages with a desire to evade the taxgather's demands, and so general has this feeling been engendered by the British public that it has been considered a clever and meritorious stroke of business to frustrate the payment of lawful impositions.

Dishonesty never seems to be applied to these 
endeavours. Individuals who would be shocked at the idea of defrauding their fellow-citizens by not paying their just debts, have no compunction of conscience in defrauding the Exchequer, and seem to ignore the fact that every shilling they withhold from the government has to be made good by the taxpayers of the country.

The bold smuggler in bygone days was invested with a certain amount of romance. Literature and art have portrayed him as an interesting individualcertainly not a person to be condemned as a robber of other people's goods. $\mathrm{He}$ and his confederates were never shunned by society, for it is an authenticated fact that when they have been caught and placed in prison, strenuous efforts have been put forth to obtain their release, their most permanent champions being the clergy and churchwardens of the parish in which they resided, who have invariably given them most excellent characters.

In most of these cases of convicted smugglers, their wives and families have become chargeable to the union. From this $\mathrm{I}$ infer that the authorities in desiring the freedom of these gaol-birds had a desire to save the parish rates the cost of maintenance of the offenders and those belonging to them.

Smugglers, like poachers, have always formed the most worthless portions of local communities. So long 
as they secured their illegal gains they were thriftless and dissolute, and when these failed, having no funds to fall back upon, became dependent on charity. Experience shows incontestably that the smuggler has generally ended his career in the workhouse; save and except men who found the sinews of war but did not brave the perils of running goods-they have fattened on the perilous enterprise of the dupes they employed.

Smuggling as a business on an extended scale received its death-blow when the duties were reduced or abolished on many articles, notably, silks, laces, gloves, tobacco, and spirits. So long, however, as duties remain in any shape, efforts will be made to run goods. In the present day wholesale attempts in the old-fashioned style have been abandoned, and the authorities have now to guard against the petty smuggler, whose only chance lies in concealment in out-of-the-way places on board steamships.

Occasionally the old spirit will revive, and in secluded spots during a dark night, a run may be effected; but we no longer hear of hidden caves, and the cellars of public houses on the beach being filled with contraband goods. Our coasts are well watched, and hamlets which formerly were little known, and had but scant intercourse with the outside world, are by means of railway communication 
accessible from all parts, and do not possess the isolation which favoured smuggling pursuits. Modern innovations have robbed such localities of their privacy; with an increased population all transactions are more widely known; the newsmonger is about, to give to the world in the daily press all that occurs, so that the fear of detection militates against any such great attempts at smuggling as formerly.

The following are a few only of the cases which occur in the Customs records of the endeavours made to evade the duties.

At the time when excessive duties were levied on French manufactures, such as lace and silks, frauds on the revenue were largely carried on through Dover and the southern ports, and notwithstanding the vigilance of the officers, the organised system of the smuggling fraternity was often successful.

Light spring-vans, well horsed, were employed in conveying smuggled goods to London. Houses were used at defined stages, where the spoils were stowed away until a favourable opportunity arose for completing the journey to the metropolis. The smugglers travelling by night only, and by circuitous routes. In the southern suburbs of London more than one palatial residence of a city merchant was designated as "Smuggler's Hall," names which are not obliterated from the minds of the villagers even at the present 
day. On one occasion the Customs officers at Dover were sent on a fool's errand. A van loaded with silk and lace had left the town at night, and to ensure it a successful journey an accomplice informed the officers of the departure, the venture being suspected. Forthwith they went in pursuit in a post chaise. The parties in the van, after going about four miles, drew into a side road, extinguished the lights, and remained quiet. The officers soon rushed by in hot haste, and when they had passed the smugglers betook themselves in another direction and got safely off with their booty.

The mania for these smuggling propensities was not, however, confined to persons engaged in trade. Couriers, z'alets de place, lady's-maids, even people of high degree, were all engaged in cheating the revenue. The carriages and baggage of ambassadors, envoys, and aristocratic personages employed in the public service were not then subjected to a very severe scrutiny, hence their packages and encumbrances were frequently used for the concealment of dutiable goods.

One energetic and conscientious officer had reason to suppose that the carriage of a noble duke returning from a foreign mission was being so employed. The vehicle was searched, and found packed with lace, which was seized. The official had, however, cause to regret the exercise of his zeal, which brought him 
no reward but a severe reprimand for stopping his "grace's chariot."

When goods were subjected to ad zalorem duties, many disputes occurred between the Customs officers and importers. Under the law the latter had the option of receiving from the government the value he put upon his goods if the officers insisted that the price was too low, in which case the articles were kept and put up for sale by the Crown.

The effect was that each quarter the queen's warehouse was an immense bazaar filled with clocks, watches, musical instruments, articles of virtu, furniture, gloves, laces, carpets, \&c., \&c., which had been detained for undervalue, and were to be offered for sale by auction.

On those days this warebouse presented a lively scene. Musical instruments were in full play all day, and the place was thronged by well-dressed folks all intent on securing bargains.

In the majority of instances the Crown obtained higher prices than had been given to the importers for their goods, and when this was the case the officers who detained the articles received the overplus-the bidders at these sales, as is their wont at auctions, running up the prices beyond what was the true worth. Jews and the agents of importers sometimes obtained goods below the sum given by the 
Crown, and as there was no reserve the revenue was the loser, and the officers got no gain. They were, however, often called upon to explain their reasons why the goods had been valued to the extent which led them to detain. Frequently the officers made mistakes, and importers laid a trap in which the unwary and inexperienced official was easily caught.

On one occasion an importer, who had an eye to business, imported into Folkestone a case of gloves and declined to pay the duty assessed on them; they were thereupon detained by the officers. Into London he imported a similar case, which was also detained for the Crown. When the goods were offered for sale at the two places it was found that the case at Folkestone contained all right-hand gloves, and that in London all gloves for the left hand. They were considered valueless, and were knocked down to a purchaser at a nominal sum. The buyer in each instance was the importer. He paired his gloves, and made a handsome profit by the transaction.

One of the most ingenious and daring efforts to defraud the revenue was attempted in the year I88I, and without doubt had been carried to a successful issue on several occasions. The discovery was entirely due to an informer.

For some time hints had come to the officials that tobacco was being smuggled on an extensive scale 
from Rotterdam to this country. The writer, however, gave no particulars, but stipulated for a considerable reward for divulging the secret he said he possessed. As similar communications of this nature were not uncommon, and the details given were so meagre, little attention was paid to him. He, however, became persistent, and gradually opened his mind. It was then determined to send a detective officer to Rotterdam. Acting on the information given, he occupied a lodging overlooking a large boiler foundery, and by strict watch on the premises, saw large quantities of tobacco carried through the gates, and from an upper floor of the house was enabled to obtain a view of what was going on inside. This tobacco, he discovered, was by hydraulic pressure packed into marine boilers, which when filled were removed and placed on board a steamer bound for one of the northern ports of England.

The telegraph informed the Customs officials at the port to watch the vessel on arrival. The boilers arrived in due course, were landed, and allowed without interference to be placed on the railway and conveyed to King's Cross, London, it being the desire of the officials to secure the parties concerned in the venture.

For several days after arrival in London the boilers remained unclaimed. At length one was 
conveyed to a railway arch at Stepney, where it was watched night and day. The second boiler at King's Cross was subjected to the like supervision by the police.

At length the parties came to the Stepney arch to claim their booty, when they were arrested, and in their presence the boiler was opened and found filled with tobacco.

The police at King s Cross gave up all hope of any one coming for the boiler there, and relaxed their vigilance; and through an informality in a telegram were informed that the goods would not be removed the day of the first seizure. The word not caused them to relinquish their vigilance on the property.

It was removed, but unfortunately for the rogues the carriage used in its conveyance broke down and the immense burden stuck fast in the Bagnigge Wells Road, and was ultimately secured.

The smugglers were convicted in the penalty of $£_{4}, 8_{24}$, and in default of payment were sent to prison; the two boilers and the tobacco contained in them were confiscated. The smuggled article weighed five tons and was burnt. The boilers were not of any commercial value except as old iron. They were made of plates too thin for marine purposes, and had evidently been put together for these ventures, and used on previous occasions for a similar purpose with success. 
The attempts at petty smuggling have been so numerous and varied that in this paper it would be impossible to enumerate them all ; but the following are some of the most curious examples of the inventive genius of the smuggler:-

A loaf of rye bread left unconcernedly on a cabin table was found filled with cigars, which had been inserted after baking.

A pitch-pot brought ashore from a vessel by the carpenter ostensibly for the purpose of being heated had an interior lining filled with spirits. This trick must have been carried out successfully for years.

A wooden fender slung over the side of a ship was hollowed out and filled with tobacco.

One individual never came ashore from his ship without a book under his arm. He was looked upon as a very studious person. On one occasion the Customs officer fancied he saw a cork attached to the book, and then found that this copy of Rollin's History was a wooden box with a tin lining filled with brandy. The delusion was successful until discovered.

Fgg boxes have been frequently employed in cheating the Revenue. The sides and heads were ganged out in holes and filled with cigars.

Women's petticoats have been found puffed out by bladders filled with spirits, and in the age when crinolines were worn often escaped detection. 
When imported watches were subject to Cistoms' duties every description of artifice was resorted to for evading the impost.

A foreigner took passage from Holland in a steam vessel and secreted round his body in leathern bandages a considerable number of watches. The weight was so great that he could not lie down, and calculating on a quick voyage of about twenty-four hours concluded that he could for that period bear the enormous strain upon his system. Unfortunately for him, the ship was detained in a fog for an additional day. At the time of arrival in London the man was completely exhausted; his courage failed him in the prosecution of his venture, fear of detection overcame him, and he gave himself up to the Customs' myrmidions, who had been watching his anxious and distressed features.

Hayling Island, Hampshire-which is now much frequented as a seaside resort-was very little known to the travelling public thirty years since. Geographically it is somewhat in the shape of a triangle, its base washed by the English Channel, its western side separated from Portsmouth by an arm of the sea called Langstone Harbour, and its eastern side is separated from Sussex by Chichester Harbour, a narrow inlet. The Sussex entrance was at one time grarded by a coast-guard force in an old disused brig, 
the Griper. From this estuary several inlets led up to farm houses, which were so close to these waters that vessels came alongside the barns to load and unload agricultural produce. If, therefore, a sloop could successfully run past the Griper she was soon safe from observation. The western arm of the sea was guarded by a military fort and coast-guard station, and if the watchmen there were not on the alert any skipper who eluded their vigilance could take his vessel anywhere he pleased. At the apex of the triangle is a long wooder bridge communicating with the mainland at Havant. There was a time, not so very long ago, when a bridge did not exist, and vehicles passed at low tide over a causeway to Havant, which is even now used when the bridge is under repair.

Tradition says that "Will Watch," the bold smuggler, the hero of our old nautical ballad, sailed out of Hayling; and for his purposes he could not have selected a safer locality.

The writer of these pages happened to be in the island at the time the following events occurred.

In the north parish an opulent farmer had an evening entertainment, and amongst the guests were the coast-guard officers of the district.

The host was called away from the whist-table, and remained absent some time, all being under the impression that home matters required his attention. 
That evening, as it subsequently transpired, a sloop laden with tobacco had run the gauntlet past the Griper and was being unloaded at one of the barns belonging to this farmer.

Early in the following morning one of this gentleman's carts loaded with tobacco was stopped at Havant, the vehicle was seized, and the carter was taken before the magistrates.

The occurrence spread quickly throughout the island-coast-guard officers and men, full of inquisitive anxiety in the matter, flocked to the inquiry, and whilst they were busily engaged in satisfying their curiosity the remainder of the cargo was successfully carted away, almost under the eyes of these guardians of the revenue; and great was their chagrin to find that the farmer had made them safe at his hospitable board whilst the venture was being carried out.

The loss of the cart and horses, and the penalty inflicted on the carter, was more than compensated by the duty saved on the rest of the cargo which escaped. There was much rejoicing in Hayling at this clever ruse, for the population always evinced sympathy for a smuggler.

Whilst importers have never failed in attempts to defraud, exporters have not been idle in getting something out of the Customs.

British silver plate, new and unused, was, prior to 
I 884 , entitled to a drawback, when exported, of the home duty paid by manufacturers through the Goldsmiths' Hall to the Exchequer.

The Customs officers carefully weighted and examined all such plate presented for drawback, and on their certificate the money was paid.

A person engaged in this plate export business possessed a silver caudelabra of considerable weight, the drawback on which amounted to a large sum, and upon being duly exported to Jersey received the amount due.

On arrival in the Channel Islands the candelabra was coated with a green compound, which gave it the appearance of beirg made of bronze. It was then re-shipped to London and examined alongside the importing vessel, and passed by the Customs as a bronze manufacture and free of duty.

The article was then taken by the owner to his place of business, the coating was washed off, and it became once more a silver candelabra. Thence taken to an outport for shipment, the drawback was obtained a second time; the process of coating was again performed at a port of France, re-introduced into England, and the same process was continued until the fraud was accidentally discovered; but not until the author of the fraud had obtained a handsome sum out of the revenue. 
A Jew had a wonderful specific for making old plate "better ash new." On many occasions he deceived the officers. At last, in his greed, he overreached himself. He produced a large quantity for the drawback, and excited suspicion by his eagerness to get the parcel passed at once. The officers decided to consult a well-known manufacturer as to some of the pieces, from whom they ascertained that the silver had been made by them for a noble marquis, used by him for many years, and at his death the plate was sold to the Jew. This proved that the claim for drawback was illegal, and the whole lot was confiscated.

An hotel keeper in Jersey did a large trade in plate sent from England, on which drawback was received. All the articles were brought back concealed in baggage. For several years the same articles claimed the rebate, and it is calculated that he deirauded the revenue of hundreds of pounds yearly until his trick was discovered. 



\section{CHAPTER VI.}

MEN OF NOTE IVHO HAVE BEEN CONNECTED WITH THE CUSTOMS. 



\section{CHAPTER VI.}

MEN OF NOTE WHO HAVE BEEN CONNECTED WITH THE CUSTOMS.

THE several departments of the State from time immemorial, which I believe in legal parlance dates from the reign of Richard II., have attracted men of note and standing in the ages in which they lived, and a glance at the public records will show that those who figure in history as persons important in their several spheres have been singled out for important employment as revenue officers. The attractions to the Customs establishments, not now alluring, were formerly of a lucrative nature; for the offices, filled by aristocratic individuals, would not of themselves have enticed people in a high social or political life but for the monetary gains attaching thereto. And this reason is sufficient to explain why the undermentioned, which are only selected as a few examples, have become associated in the collection of Customs duties. So long as the posts in this branch of the 
imperial service were sinecures, nominees for the favour of the State were always forthcoming from the higher ranks of society. The ministers thus found to their hand a ready means for satisfying political claims, and conferring a recognition on men of letters who had been useful to them.

Foremost amongst these worthies stands Geoffrey Chaucer, the father of English poetry, who was sent in $\mathrm{r} 373$ to Genoa, to hire ships for the service of Edward III. On his return he was appointed to the Comptrollership of Customs on Wools, and had a grant of a pitcher of wine a day, to be delivered by the Butler of England, and amongst his emoluments had a share in the seizures of contraband wools. He also enjoyed a royal pension of twenty marks, equal to $£ 24$ a year. How long he continued to fill the post of Comptroller of Wools is uncertain, but possibly not longer than ${ }_{1} \delta_{3}$, when he was elected knight of the shire of Kent. At all events he ceased to hold his Customs office in 1389 , when he became clerk of the works at Westminster, of Windsor and other palaces. In the following reign, Henry IV., he had to leave the country on account of his religious opinions, but returned and died in 1400 .

William Congreve, the dramatic poet, who was a commissioner of the Hackney Coach Office in r693-4, held also a situation in the Customs of 
$£ 600$ a year. This must have been some patent office; his name does not appear amongst the list of commissioners, nor can it be ascertained how long he held office; he died in 1729.

Nicholas Rowe, the dramatic poet, born in 1673 , was appointed Secretary of State on the accession of George I., I714; made Poet Laureate same year, and appointed a landing Surveyor of the Customs, London. He died in $17 \times 8$, so that his occupation of office in the revenue only lasted four years.

Matthew Prior, the celebrated poet, born in 1664 , was Secretary at the Treaty of Ryswick, I697, and afterwards a Secretary of State, and in 17 I 3 , Secretary to the embassy in France. He appears to have also filled the post of Commissioner of Customs from I 7 II to 1724 , at a salary of $£$ rooo per annum; died $172 \mathrm{r}$. He was arrested and committed to prison by order of the House of Commons in $17 \times 5$, but recovered his liberty in $17 \mathrm{I} 7$.

Sir Dudley North, brother of Lord Guildford, keeper of the Great Seal, temp. Charles II. and James II., Sheriff and Alderman of the city of London, was a Commissioner of Customs in 1684 to 1688 . He was also a Lord High Treasurer in 1684 and $169 \mathrm{I}$.

Adam Smith, the celebrated political essayist,

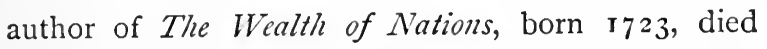
$179^{\circ}$; said to be commissioner, I $78 \mathrm{I}$, for Scotland. 
On a recent visit to Poets' Corner in Westminster Abbey, I could not help thinking that this was our Custom House Corner, as I gazed on the monuments erected in honour of Chaucer, Congreve, Rowe and Prior, all Customs men, who in the flesh had played a prominent part in collecting the revenue in Lower Thames Street.

The first Earl of Liverpool was Collector of Customs inwards, I792, as were also

The Duke of Manchester, Collector outwards.

The Duke of Newcastle and the Earl of Guildford, Comptrollers, inwards and outwards.

Lord Stowell, Surveyor of Subsidies and Petty Customs.

Sir Richard Temple, Commissioner, I675.

Lord Southwell, Commissioner, Ireland, I 720.

Sir Francis Hastings Doyle, baronet, Professor of Poetry at Oxford, and a distinguished man of letters, was a Commissioner of Customs for several years, and resigned in 1883 . He was a most genial and valuable member of our Board, and greatly esteemed in the Department.

In the present century we have had but few members of the Upper House who have taken seats at our Board.

The late Lord Clarendon, when Mr. Villiers, was a Commissioner from 1824 to $\mathrm{I} 833$, and the Earl of 
Arran, who has recently been raised to the House of Lords, was amongst us for a few months last year, 1884 .

The post of a Commissioner is not, as formerly, a sinecure. The present Board take a very active part in the administration of the Department. They go circuit, so to speak, and are none of them unknown at the several Custom Houses of the United Kingdom. 

CHAPTER VII.

THE PRESENT AND FORMER CUSTOM HOUSES. 




\section{CHAPTER VII.}

THE PRESENT AND FORMER CUSTOM HOUSES.

As far as can be ascertained five Custom Houses have been built for the purpose of carrying on the business in the port of London.

The first is stated to have been built by John Churchman, Sheriff of London, in $\mathrm{I}_{3} 85$, and stood on the site of the present building; but what description of edifice it was I have not been able to ascertain.

The second was erected in Queen Elizabeth's reign. It was destroyed in the great fire of I666. A view of this building, copied from an old and scarce print, is annexed as the frontispiece to this work.

The third was built from the design of Sir Christopher Wren in 1668 on the same site, at a cost of $£$ Io,000. This House was burnt in I III, and was the only one of his buildings destroyed during his lifetime. 
The fourth was built by Ripley, who introduced a "long room," and stood immediately east of the existing building, it had a fine river front, but was greatly altered afterwards. Views of Ripley's Custom House are given showing the original design and the subsequent alteration.

On the I 2 th January, 1814 , this building was discovered to be on fire, and so rapidily did the flames do their work that it was soon doomed to destruction.

In the brief account given in the Times of the $1^{\text {th }}$ following, it is stated that a panic set in amongst the firemen and bystanders. A large quantity of gunpowder belonging to the Custom House volunteers, then enrolled, exploded, sending that part of the building in all directions--papers and documents were flying before a high wind blowing, and were picked up at considerable distances.

The building was in charge of a lady, Miss Kelly, who held the post of housekeeper as a sort of sinecure, and occupied one of the best portions as her apartments. The fire originated in rooms attached to her brother, Colonel Kelly, who resided on the premises. Unfortunately two of this lady's servants were burnt to death. They would seem to have been forgotten in the hurry and desire to save Miss Kelly's valuables and some pet animals and birds who, like herself, had free board and lodging in the Custom House. 


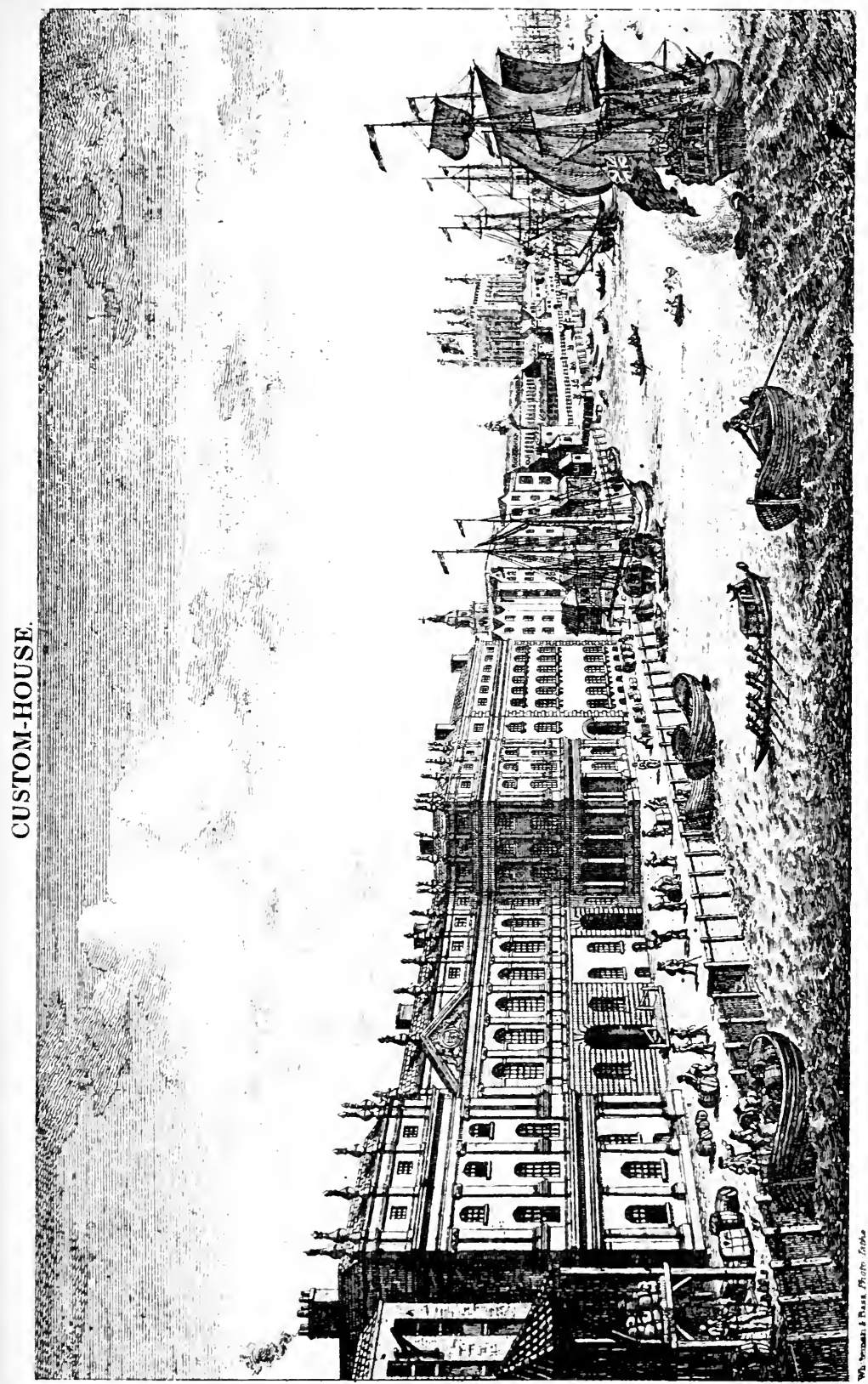

告 



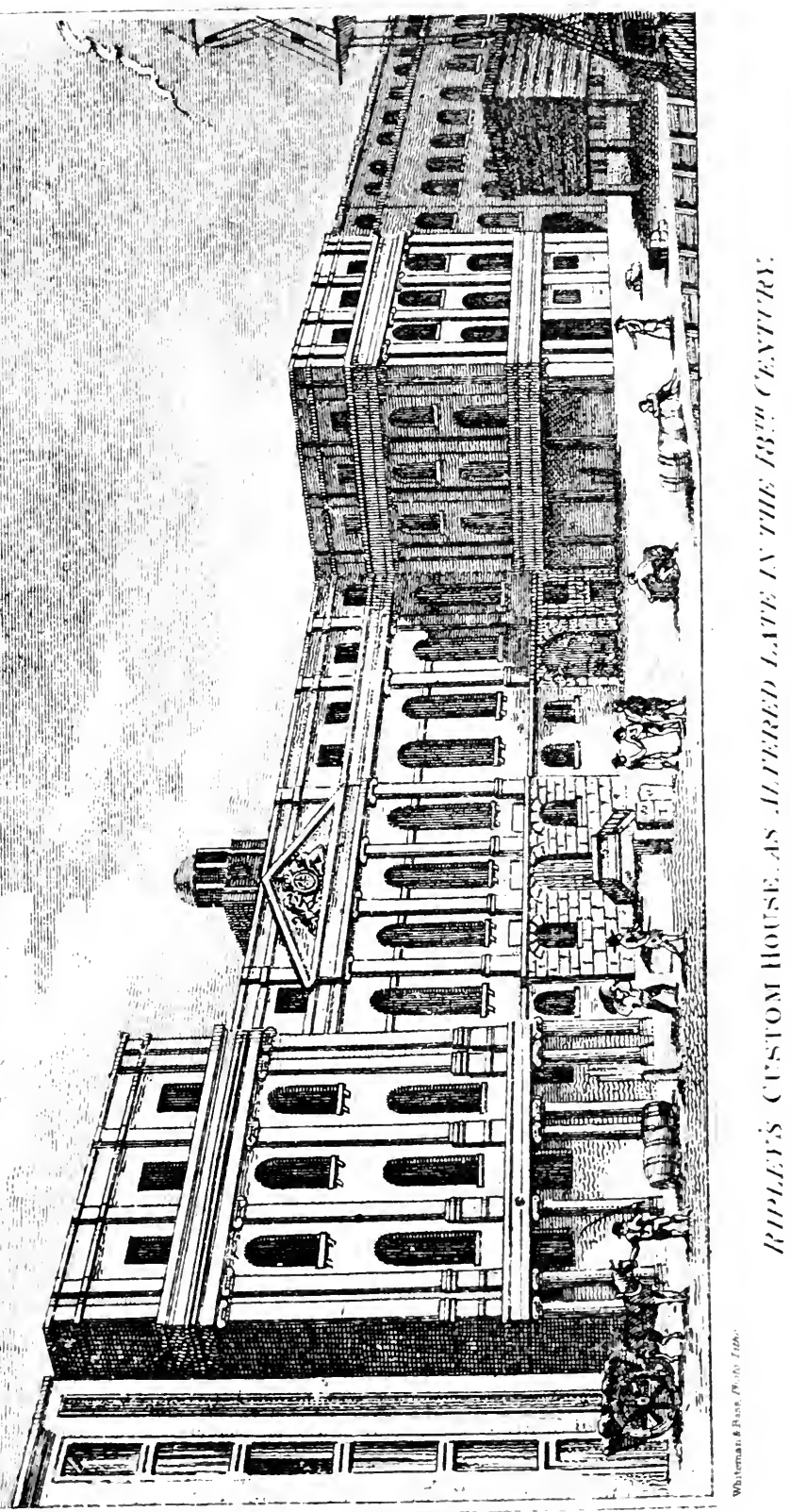



The building at that time was the depository of valuables of every description-plate, jewels, silks, china, \&c., awaiting payment of duties which were lost. Plunderers, however, who were on the scene, laid their hands on everything within reach; some were caught flagrante delicto, and were dealt with according to law, and doubtless swung in mid-air at the Old Bailey, as was the custom in those days for such offences.

Much commercial and departmental inconvenience resulted from the fire, the several offices being scattered in places hired for the purpose in the city.

The government of the day had previously decided to alter the site of the Custom House, and had purchased all the quays, wharves, and buildings between Water Lane end of Thames Street and Billingsgate, to the westward of the former Custom House. The amount paid for the freeholds acquired was $£ 41,700$, and before the destruction of the old building the plans for a new building had been drawn up, and the work of construction commenced. From a drawing of what was intended to be the river frontage, and if it had been carried out in its entirety London would now be able to boast of one of the handsomest fronts to be seen on the banks of any river; and although, as it now stands it is imposing, in appearance it cannot vie with Somerset House, the palatial edifice erected by Sir William Chambers. 
Mr. D. Laing, the surveyor for Customs buildings, was the architect; it was commenced in $\mathrm{I}_{8} \mathrm{I} 3$ and occupied in 1817 , the cost being nearly three-quarters of a million sterling.

The contractors had in their estimate miscalculated the difficulties with which they had to contend; the soil was treacherous, and for a long time they were unable to secure proper foundations. By dint of much perseverance and labour the building was completed.

The new Custom House was opened for business in 1817 . It was erected at a cost of about $£ 300,000$. In 1825 the centre portion gave way, the long room falling in bodily, but no injury to life occurred. The Crown's officers considering that the foundations had not been properly constructed, commenced an action against Mr. H. Peto, the contractor under the bond, for the recovery of penalties. The case was tried in the Court of Exchequer in May, I826, and experts on both sides were examined. In the course of the trial it was proved that Mr. J. Laing, the Crown's architect, and his subordinates had given directions to deviate from the particulars of the contract, and ordered beech piles to be used for the foundations contrary to the expressed opinion of the contractor. It was shown that the use of these piles was the cause of the disaster, and the jury found in favour of the contractor, so that the public had to 


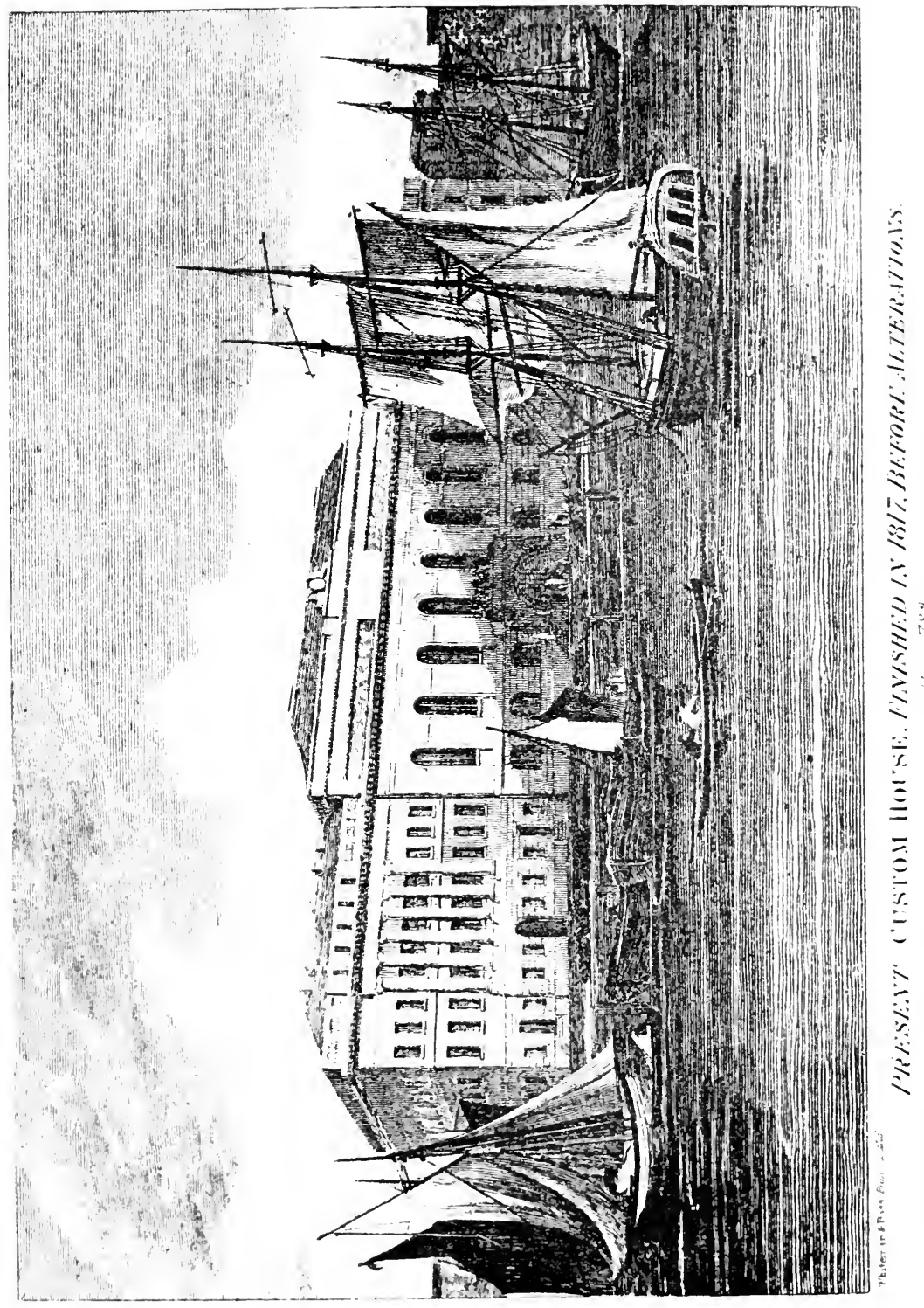



grin and bear the loss. The edifice was securely underpinned, and the foundations made so secure that no further damage to the fabric has taken place.

The long room in the present building, the roof of which has no intermediate support, is considered the largest and handsomest in England, it measures 199 feet by 66 feet, and up to $185^{\circ}$ was not greater than was required for official purposes. Here was a busy scene from ten to four, merchants and their clerks coming in and out on business. In old guide books the Long Room of the Custom House was designated as one of the sights of London to be viewed by visitors to the metropolis. This room, compared to its former attraction, is a waste, and the public attendance comparatively small to what it was. Miss Kelly, the former housekeeper in the old building, which her relative was supposed to have been the innocent cause of destroying, retained her post in the new edifice, and tradition says she was a gay and lively party, much given to musical entertainments, and that she used the long room for her gatherings, in which the voices of Braham and Lablache were heard to great advantage.

There is nothing now at all of an attractive nature to induce a visit to Thames Street to view the Custom House; there are no bargains to be picked up at the periodical sales; the Queen's warehouse no longer 
holds articles of virtu-extravagant furniture, musical instruments, watches, silks and cigars. In their place will be found some derelict goods and a few articles which are of interest oniy to a general Jew dealer or the keeper of a marine store.

The Board room is handsome and possesses two full length portraits by Sir T. Lawrence of the sovereign George III. and the Prince Regent, although replicas they are of great artistic value; the originals are placed in the Royal Galleries of Windsor and Buckingham Palace.

As Billingsgate fish market is a close neighbour it is perhaps out of taste to disparage it, but those who have to do business at the Custom House always regard it as a nuisance.

For several generations this market has been the source of complaint, and at the present day occupies a large share of attention in the public press.

The thoroughfares from daybreak have been from all time blocked by a motley mob of the lowest of the low, and the language used has become a byword all over the globe, so much so that uncomplimentary terms are aptly and rightly termed, "Billingsgate."

With every endeavour that has been made, these savages, for they deserve no better name, are untamable, and I know of no more fitting scope for the missionary labours than this locality, to which the 
lawless and idlers of every degree daily resort. As evidence of the low state of morality pervading hereabouts, I may mention that in my recollection, not many years ago, it was a condition in rowing for a certain prize in the "Billingsgate Regatta," that all the competitors should have served three weeks in the gaol of Newgate.

Few people in affluence as they partake of the dainty dishes of fish placed before them, are aware of the hardships undergone in obtaining these denizens of the deep, and how much roguery and blasphemy pervades the spot where the delicacies are sold.

I do not think that in any other market in the world, fish and blackguardism are so closely associated.

In the olden days, the drop at Newgate on a Monday morning was considered a place whereat to observe the character of the lowest strata of our population. A visit to Billingsgate on any Monday will afford to the moralists and the philanthropists much whereon to speculate, and an unending field for their labours in the cause of reformation and improvement. 



\section{CHAPTER VIII.}

DEPARTMENTAL CURIOSITIES. 



\section{CHAPTER VIII.}

\section{DEPARTMENTAL CURIOSITIES.}

THE departmental records are full of quaint old orders affecting Customs officers, and especially in regard to their religious opinions. Roman Catholics, as we are aware, were anterior to 1829 disqualified from holding government appointments; but it may be new to many of our readers to learn that men of a very inferior grade were dispossessed of their posts not only on account of their belief, but because their relatives were suspected of heresy to the orthodox Protestant faith : for we find the following remarks :-

In 1688 the Right Hon. Sir N. Butler and the Hon. Henry Brown, commissioners of Customs, had their salaries stopped, both being Papists; and three surveyors, and four landing waiters, and one tidesman, were similarly dealt with.

In 17 I9 Samuel Morris, a gauger at Ballina, was dismissed the service upon repeated advices from 
Mr. Hutchenson, a J.P., that this man's wife is or was lately a Papist.

And in the same year Henry Dillon, a tidewaiter at Limerick, was dismissed for having refused to drink some loyal healths.

Bribery and corruption have in all ages been utilised to obtain advancement in the civil departments of the State.

The following extract is a curious example of the practice in vogue in Scotland in the year 1754 . The collector of Customs at Kirkwall had been surcharged by the accounting officers at Edinburgh the sum of I $4 s$. $2 \frac{1}{2} d$., duties short collected on some oil, and in his letter explaining the circumstance to the assistant accountant-general and his clerk, he adds :-

"I wrote to you formerly that my salary here is so small, but forty pounds sterling yearly, and little or no 'perquesates,' that I am scarce able to mantain my family upon it, considering the dearness of living in this country, without running for debt, that I am not able to give you the same qualifications for your trouble that other collectors doe; however, I shall order my doer (sic) that uplifts my salarie this currtt. quarter to give you a small acknowledgement as I am able."

Here is complete evidence that these examiners were to be bribed into passing public accounts, but 
that they were willing to exact a toll on any increase of salary they could procure from those whose receipts they had to control.

'The offer of the bribe by the collector of Kirkwall would not appear to have been attended with success, for in subsequent correspondence with these worthies they were very exacting in checking his accounts, and he displayed considerable temper in combating their surcharges.

During the present century inferior officers in Scotland were paid only $£_{3}$ a year, with a shilling a day extra when employed by the Customs. In the winter and slack times they were not engaged; the consequence was that many of them had to resort to the parish for relief.

In the year 1849 much excitement prevailed in consequence of the murder of Patrick O'Connor by one Manning and his wife, of which crime they were found guilty and hanged at Horsemonger Lane Gaol.

The victim Patrick O'Connor, an Irishman, was a Customs gauger of very dubious character. He had frequently been a source of trouble to his superior officers. He was a money-lender on a small scale, and very much hated by the lower classes who became indebted to him. $\mathrm{He}$ had considerable influence with dock officials in getting his fellow-countrymen 
taken on as day labourers. The "sons of Erin" flocked to Patrick O'Connor for employment, and from these wretched men he exacted a weekly payment out of their earnings.

His murder was the result of improper relations with Mrs. Manning, and many who had reason to know him well said he richly deserved the fate that befel him.

Within the last fifty years the higher officers of Customs were surrounded with a certain amount of state. A beadle clad in gorgeous uniform, carrying a silver mace, preceded the Collector in London when proceeding to the Board. Scarlet robes and gold lace were generally worn by underlings, and landing waiters on duty were attired in court suits with swords, knee breeches, silk stockings, and silver shoe buckles. Now alas, there is nothing to denote such personages, the plain uniform of a blue frock coat and gilt buttons, with an ordinary cap, little different from a petty officer in the Mercantile Marine, is only worn by the out-door officials who are brought into contact with the outside public.

The only remnants of the gorgeous uniforms formerly prevailing are to be found in the constables who guard the principal entrances to the Custom House, attired in large scarlet robes and cocked hats.

Considerable rivalry appears to have existed formerly 
as to the post of preference between the Board of Customs and the Board of Excise, now styled the Board of Inland Revenue, and the matter must have been discussed and settled in $\mathrm{I} 72 \mathrm{I}$, for I find an entry in the Minutes of May 26 th in that year stating :"Commissioners of Customs and Excise when they attend at the Treasury at the same time, the Commissioners of Customs are always called in first."

The Board of Customs have always been styled the honourable commissioners, whilst the rival Board of Excise were simply called the commissioners. The frequent prophecy that the two departments would be amalgamated appears to be near its fulfilment. What benefit may accrue by the union to the officers concerned is impossible to foreshadow, but the commissioners of Inland Revenue may thereby attain the prefix of "Honourable."

From some valuable old books, which by some means escaped the ravages of the fire in 1814 , I gather the following curious entries:-

I 7 19. April 27.- - In order to a frugal management of this revenue, as well as an example to officers, the Commissioners of Customs resolve that for the future they will themselves pay for such coffee, \&c., \&c., as they may have for their breakfast, and pay for such books and pamphlets as they may want. 
I was at a loss to understand why the commissioners gave so early an attendance as to require breakfast, but I find from several subsequent entries, that members of the Board attended in the Long Room as early as seven A.M., to sign cockets.

The practice of living at the expense of the Exchequer continued until a much later date, certainly not fifty years since.

These free breakfast tables, luncheons, and meals, were discontinued later on, and very different opinions on the propriety of officers being refreshed at the cost of the public, were entertained, and dismissal from the service has been since carried out in cases where officers have regaled themselves when on duty at a merchant's expense.

There must have been considerable dignity and etiquette prevailing in the Customs Board-room in days gone by, for it appears that in 1720 it was decided by a solemn letter that "the patent officers in the Bench having been allowed a chair when they attended the Board, the Commissioners think fit to allow a like indulgence to the Receiver-General and the Comptroller-General."

In I725 an entry appears to the effect that the commissioners went into the Long Room to sell an estate under an extent to the highest bidder. What this sale refers to I am unable to state, probably to 
some property in the West Indies, for at that time slavery existed there and the mother country advanced money to the holders of estates, since the Commissioners of Customs for some time after secured in bond under their care the produce of rum and sugar for several islands, in settlement of advances ; possibly these sales may have been foreclosures of mortgages.

There are entries of subsequent sales of this description, for I find injunctions issued for keeping order at such sales, and payments were made for furnishing Boards, \&c., for the occasion of sale, with remuneration in respect to cleaning the room after the auction.

The officers of Customs and Excise did not get on together very well in former times, and the rivalry between the two Revenue Boards which certainly existed up to $\mathrm{I} 72 \mathrm{x}$, as mentioned in previous notes, would not appear to have calmed down in 1763 , since the Commissioners of Customs found it necessary in that year, to enjoin their officers " to live in harmony with and to be assistant to those of the Excise." Happily in the present day no such injunction is necessary. Harmony certainly prevails between the two departments, and if there be any rivalry it is in the effort to benefit, as much as possible, the public with whom they have business.

The interference by Custom House officials in public 
matters was, until recently, attended with some danger to the revenue officers. During the Scotch rebellion of 1745 , the government took every means in their power to ascertain whether their civil servants were loyal and true. The following extract of a letter from the collector at Montrose to the Customs Board at Edinburgh, July I I, I 746, shows what befel his colleague as a suspected person.

"Yesterday, about 4 o'clock in the afternoon, Peter Skinner, Comptroller of this Port, was put under confinement by the officer who commands his Majesty's forces here. Mr. Skinner was a member of the old 'Councell' of this Burgh, and the old Councell was appointed by the Rt. Honble. the Lords of his Majesty's Privy Councell to ellect upon the soth inst. a new Councell and Magistratts for this Town, to continue till the Anuall Election; and as I'm informed the $\mathrm{s}^{\mathrm{d}}$ Mr. Skinner $\mathrm{w}^{\mathrm{t}}$ some others voted for James Coutts to be provost, who some days before was by Warrant from his Royal Highness the Duke of Cumberland taken up and sent Prisoner to Perth for Treasonable Correspondence and Criminall Practises. This I understand is the Crime for which the Compt ${ }^{\mathrm{r}}$ is now a prisoner.

J. S."

On July I 7 th, I 746 , the Board suspended Mr. Peter Skinner, but he was released by the Duke on 
the following day. A subsequent entry notifies that he died on September I Ith, I 749 .

During the rebellion the Custom House at Montrose was pillaged by a party of the Highland army; and in August, I 746, the collector reported that the "rebells" carried off six of the king's half-hundred lead weights, which it was presumed they had run down for making balls.

August 2 2nd, I 748, the collector notifies the seizure of a box " $\mathrm{q}^{\mathrm{t}}$ Syrop of Maiden Hair and Hungry Water." These compounds, I believe, are not known in the present day.

On September 7 th, $173 \mathrm{I}$, application was made at Montrose to register a new ship of 50 tons, which the bill of sale stated was built at West Stockwith in Nottinghamshire. It would seem that at this time shipbuilding was carried on very far up the river Trent, many miles from the sea; no such trade appears carried on there now.

January 8th, r73I. The officer commanding the troops in Montrose informed the collector that he would keep no guard in the night time to assist the Customs officers unless he was furnished with coal and candle.

January IIth, I734-5. The officers at Montrose had great difficulty in conveying seizures, so that the collector writes, "The smugglers and country people 
hereabouts are turned so impudent and unruly that it is in vain for the officers of the revenue to carry off a seizure in the county without being backed by the military:" in fact, from the correspondence of the period, soldiers were more instrumental in effecting seizures than Customs officers, and many broils between them and the civilians are recorded. During the rebellion it would appear that the celebrated Admiral Byng was in charge of the king's ships on the coast of Scotland, and on several occasions cooperated with the Customs and military.

In 1780 the Commissioners of Customs issued a general order to their officers, in which they stated, that, as the smugglers had become so bold as to threaten to sink the revenue cruizers, and consequently the seamen would not engage with them, the Commissioners therefore allow an annuity of $\mathcal{E} \mathrm{i} \circ$ a year to every mariner who should lose a hand or a foot.

This is a peculiar admission, and one which does not redound to the valour of the revenue defenders; and why the loss of a hand or foot was considered worth $\mathcal{E}$ ro a year, and the loss of an eye was not recompensed, is difficult to understand. Smugglers at that period must have been veritable "Van Tromps" on our coast.

Privateering was much in vogue about 1780 , for the Commissioners allowed "letters of marque" to be 
taken out by commanders of cruizers with the understanding that they should not go off their stations, and that the Commissioners would not bear the expense of any damages incurred in engagements; which meant, "you may fight if you please, but you must bear the consequences." However, there is no doubt that the prize-money to be obtained was sufficient inducement to engage an enemy's ship at all hazards.

Unfortunately no records remain to show to what extent this privateering was carried on, at all events, not in the Customs Department.

The oaths administered to Customsmen, searchers, comptrollers, and others in early times was to the following effect, as shown by the book of Oaths published in $\mathrm{r} 689$.

"Ye shall swear, that well and truly ye shall serve the king in the office of Comptroller of the king's Customs and Subsidies, in the place of Customer, and truly ye shall enter all the goods and things customable, the which shall come to the said Port or shall pass from the same; and that ye shall no gift take for to do your office, nor for anything that may fall in disadvantage of the king, nor any merchandize nor any thing customable, ye shall not suffer to pass out of the said Port, without Custom due paid ; and ye shall do the office yourself, and dwell thereupon in your proper office, without making any deputy or substitute under 
you; and ye shall write the rolls with your own hands, and the king's profit ye shall await, and do in as much as ye may after your knowledge and power, as God you help and His saints."

This oath was doubtless in force in time of Charles I. 


\section{RÉSUMÉ.}

From the aforegoing remarks it appears that in the collection of the duties imposed upon the importation and exportation of goods, every conceivable difficulty has occurred in securing payment of the revenue imposts.

Farming, which began in remote times, was an easy method of securing a given sum to the crown, and relieved the sovereign of trouble, inconvenience, and responsibility. A civil establishment, as now existing, was avoided; and the sale or lottery of the dues placed in the power of the monarch, or his ministers, a means of satisfying the claims of courtiers and persons under pecuniary obligations to the State. In fact, but for this mode of enriching the Crown the sums required would not have been forthcoming; they were, however, only obtained at an usurious rate. Money for the purposes of war and the wants of the sovereign was hard to get except upon loan, and as 
the sums were always required in advance it was the rule to hypothecate the revenue coming due. Such is, and has always been, the case with impecunious individuals, and the monarch was ever ready to make grants to those who would come forward with cash in hand.

In our own days the system of farming has not entirely exploded. Turnpike tolls have been farmed to a very recent date, and even now parochial authorities let out to the highest bidder the privilege of scavengering and the repair of roads, leaving to those who contract to make as much as they can by their ventures; and so in minor matters for a lump sum down. Revenues are let to those who will bid for them. As regards the State, however, the system is at an end, with considerable advantage to the tax-payer. The receipts are duly paid into the Exchequer, and the Crown farmer no longer exists.

It will also be observed that the desire to cheat the revenue of Customs imposts has always prevailed, and so long as duties are leviable in any undue proportion to the value of the article attempts to defraud will always be forthcoming, in a greater or less degree. And, although in the present day in England smuggling is confined to the articles of tobacco and spirits, which bear high imposts, still the inherent vice of trying to defraud the government remains, and will continue so 
long as duties are imposed on goods which are extensively consumed, especially tobacco. The habit of smoking is more prevalent than it was fifty years since; the population has increased, and the population using the "grateful" weed has been augmented, but the revenue from tobacco has not proportionately increased in the same ratio; from which it is inferred that a large quantity finds its way to the consumer without payment of duty.

The snuffing propensity is not carried out to the same extent as formerly, but this is due to a "fashion" no longer followed. Large quantities of tobaccostalks, i.e., the fibre of the leaf when stripped, used largely in the manufacture of snuff, are illegally landed, but do not find a legitimate market in the shape of snuff. The government in recent years has given great relief to tobacco manufacturers in allowing them a drawback of duty paid on their refuse, under the name of snuff. The process of affording this relief is to permit bags of snuff to be sent to the Custom-house; these bags are weighed and examined, and drawback is paid on delivery according to a regulated scale. This snuff sent in by the makers is carried away in ship-loads and cast into the sea. The quantity so received and destroyed in $188_{3}$ was $\mathrm{I} I 7$ tons, the drawback paid being upwards of 2590,000 , whilst the gross produce of Customs duties on tobacco 
and snuff was nearly nine millions sterling; so that the home manufacturer received back one per cent. of the revenue collected. With these advantages the tobacco and cigar manufacturers ought to be doing well, but whether they profit largely by the payment of the drawback I cannot say. The home manufacturer of tobacco, cigars, cigarettes, and snuff, without some adventitious aid from the government would doubtless be placed at a disadvantage in competing with the foreigner. The latter, although paying a duty on all his imports, finds a market for the whole quantity. But the Englishman pays duty on the raw material, and in his factory is unable to use up the whole, and the residue or waste would be a loss not only of the duty paid on such waste but also the cost of the material unused, and therefore the legislature gives him protection by refunding the duty on what becomes a comparatively worthless article of trade.

And as a general rule this principle is admitted in respect to all goods on importation, for duties are not exacted on articles which are deposited in bond and are not found marketable. They are abandoned and the duty is not enforced, but then the articles are destroyed and do not go into consumption in the country; so that, taken broadly, duties are not enforced on goods which are not saleable to the consumer.

The Customs facilities which have been introduced 
into the warehousing system of late years have doubtless tended greatly to make England the chief depot of the world for first-class goods, especially tea and coffee. London is the chief market for these products, and will remain so as long as an enlightened and liberal system continues in our bonding system. The cost for revenue officials is no doubt large in weighing, guarding, and keeping accounts of goods in bond, in respect of which the government of this country derives no benefit whatever directly when they merely come here for a market and are exported; but indirectly the nation gains by the large employment of shipping, which pays dues and charges, by affording the means of sustenence to persons employed in the discharge and manipulating the goods, and to merchants and others concerned in the trade, whose gains for their services are spent to the benefit of the public at large. Therefore the fact of England becoming an entrepot for the world's produce is a source of wealth which is disseminated for the nation's good.

As to the personel of the Customs department in England, there is no doubt it will compare favourably with that of any foreign government. With us bribes are unknown in the present day, and importers and travellers are not subjected to the vexation and annoyance prevailing abroad. Merchants have no difficulties placed in their way as in former days in 
paying duties. The requirements are reduced to a minimum, and except in difficult cases a merchant knows what he has to pay and can clear his goods without the slightest inconvenience. In fact, the system has from past experience become so matured that there seems little to amend, and the greatest compliment that can be paid to a nation is the fact that, during recent years, many foreign governments have made application to our department to be furnished with statements of our mode of procedure in carrying out the English Customs regulations, with a view of amending their own upon our model; so that we may hope that the day is not far distant when foreign Customs vexations may be entirely removed.

The collection of a revenue of over twenty millions annually is not secured without a large amount of labour, patience, and responsibility; but it must be admitted that the manner in which the work is now performed is a great improvement on the older systems which have been imperfectly portrayed in this book. 


\section{APPENDIX A.}

\section{EXAMPLE OF AN INWARD DUTY PAID ENTRY \\ IN 1784 .}

20 Reams French Royal Paper for the new Duties.

Io Reams Atlas Fine.

Io Reams Super Royal Fine.

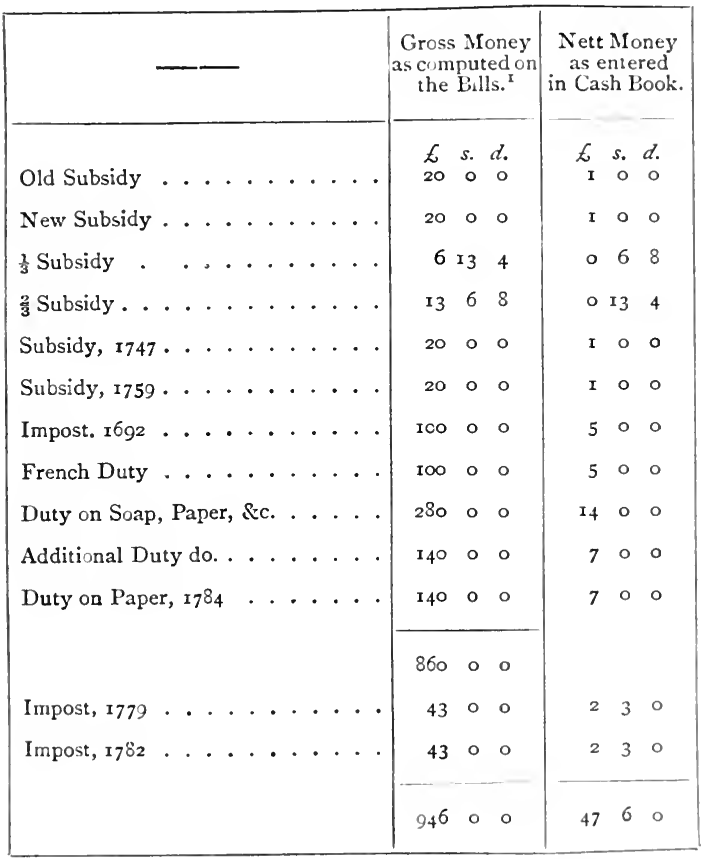

It was the practice at this time to compute the duties at twenty times their amount in the first instance. 


\section{EXPLANATION OF THE PROCESS OF COMPUTATION.}

This article is rated at $£ \mathrm{I}$ the Ream; the amount, 20 Reams, is $£ 20$.

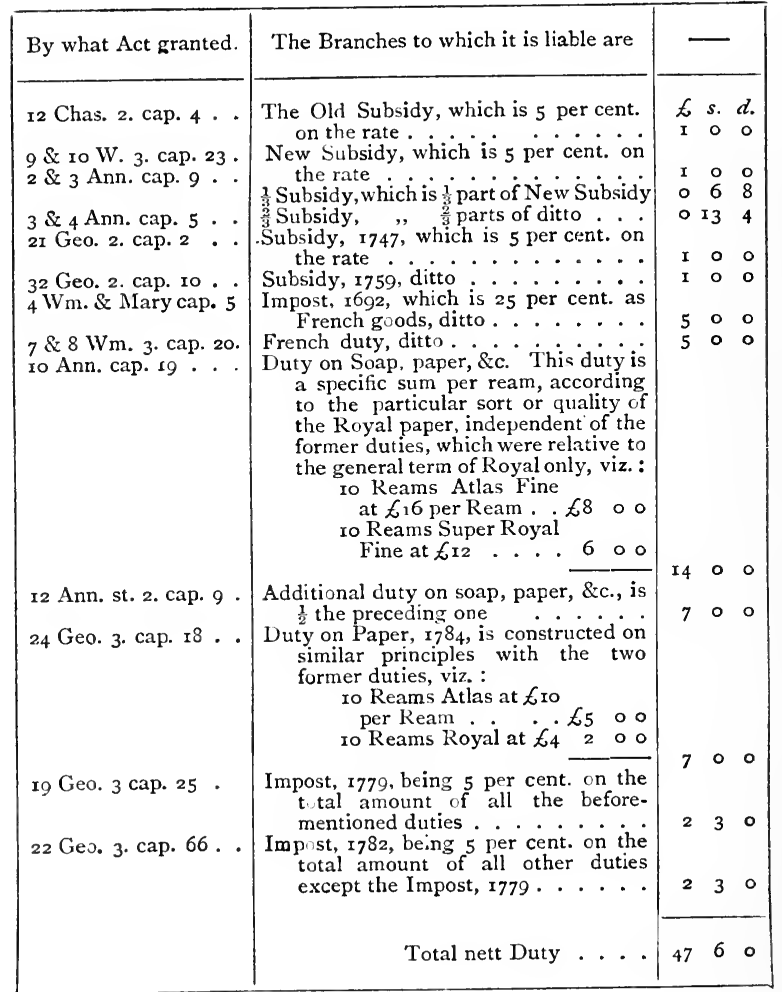




\section{A LIST OF BOOKS}

ON

\section{DPlant=ilore, Garocn=Craft, Doctry, Elngling, JBiblíograpby, \&c., \&c.,}

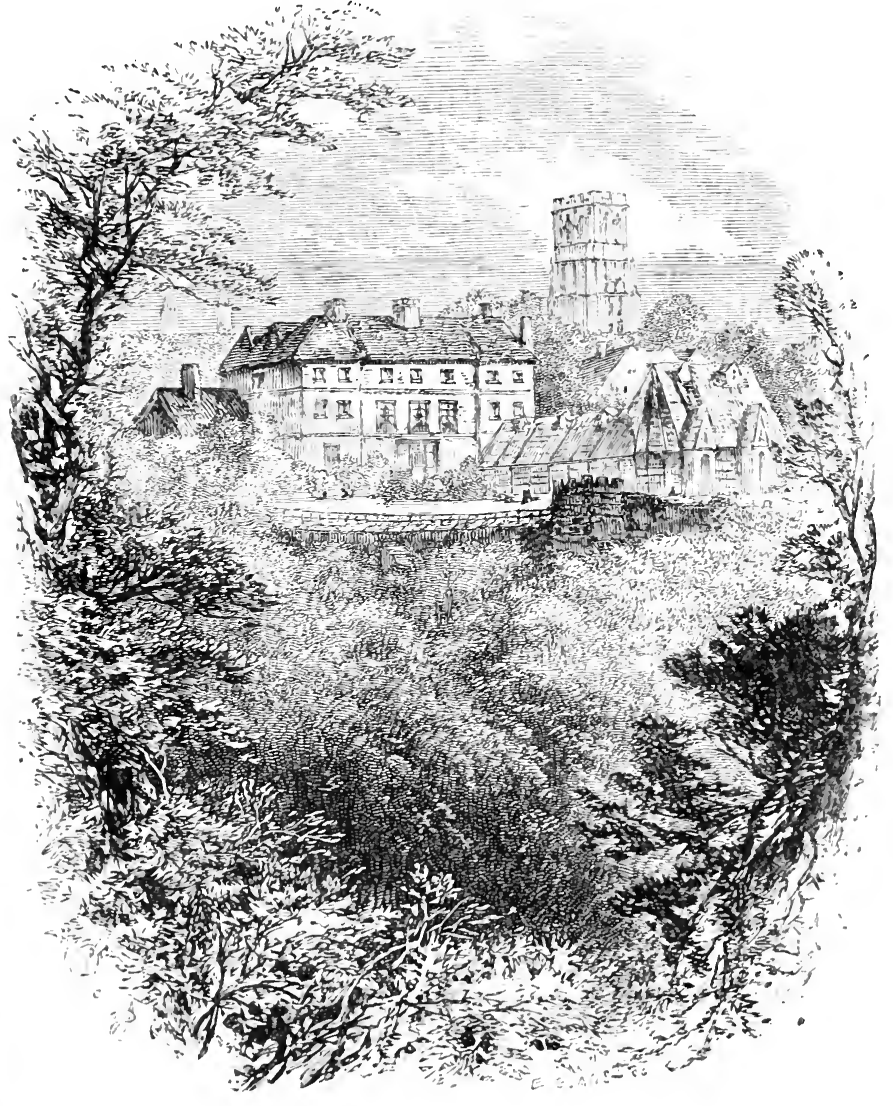

Sold by

SIMPKIN, MARSHALL, AND CO, AND ALL BOOKSELLERS. 
The Botanist, the Antiquary, and the lover of Poetry and of

Flowers, will be equally attracted by its Learned, Chatty and Useful Pages.

THE REV. CANON ELLACOMBE'S

\section{PLANT LORE}

\section{GARDEN CRAFT OF SHAKESPEARE}

The Second Edition Greatly Enlarged.

Crown 8vo, Cloth, Gilt Top, Ios. 6d.; Extra, i2s.

"It would be hard to name a better commonplace book for summer lawns. . . The lover of poetry, the lover of gardening, and the lover of quaint, out-of-the-way knowledge will each find something to please him. . . It is a delightful example of gardening literature."-Pall Mall Gazette.

"Mr. Ellacombe, with a double enthusiasm for Shakespeare and for his garden, has produced a very readable and graceful volume on the Plant-Lore of Shakespeare."-Saturday Review.

"Mr. Ellacombe brings to his task an enthusiastic love of horticulture, wedded to no inconsiderable practical and theoretical knowledge of it; a mind cultivated by considerable acquaintance with the Greek and Latin classics, and trained for this special subject by a course of extensive reading among the contemporaries of his author: and a capacity for patient and unwearied research, which he has shown by the stores of learning he has drawn from a class of books rarely dipped into by the student-Saxon and early English herbals and books of leechcraft ; the result is a work which is entitled from its worth to a place in every Shakespearian library.' - Spectator.

"The work has fallen into the hands of one who knows not only the plan's themselves, but also their literary history ; and it may he said that Shakespeare's fluwers now for the first time find an historian."-Field.

"A delightful book has been compiled, and it is as accurate as it is delightful." - Gurdener's Chronicle.

"Mr. Ellacombe's book well deserves a place on the shelves of both the student of Shaliespeare and the lover of plant lore."-Journal of Botany.

"By patient industry, systematically bestowed, Mr. Ellacombe has produced a book of considerable interest ; . . . full of facts, grouped on principles of common sense about quotations from our great poet."-Guardian.

"Mr. Ellacombe is an old and faithful labourer in this field of criticism. His 'Plant-lore and Garden-craft of Shakespeare' . . . is the fullest and best book on the subject."- The Littrary World (American). 


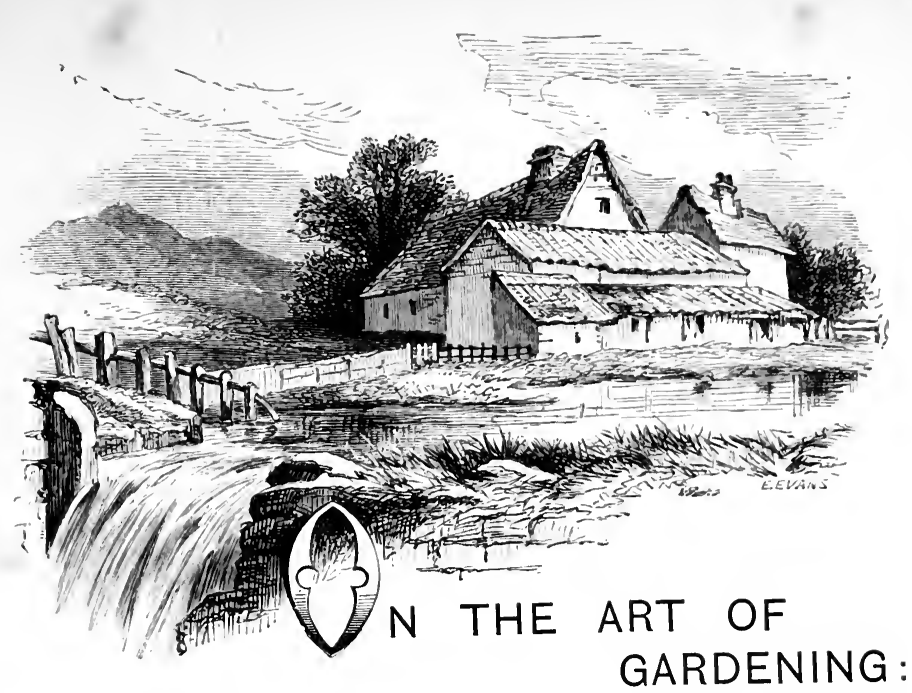

\section{A Plea for Exglish Gardens of the Future, with Practical}

\section{Hints for Planting their.}

\section{By MRS. T. FRANCIS FOSTER.}

Crown 8vo, paper cover is.; cloth, $2 s$.

"In this pleasant and original little bo $k$ the authoress not only enters a vigorous protest against the bedding-out system and the so-called 'natural' style of gardening, but gives very' good practical advice for gardens of a different sort."-Gardener's Chronicle.

"This little book proceeds from a true lover of flowers, and will be welcome to all who take an interest in their care and culture."-Civilian.

"A pleasant and unpretending little volume."-Saturday Roriez".

"The charm consists in its author's evident love of her subject. Like a true lover, she has gone far and wide in her search for old plants and old plant-lore. WVe agree with Mrs. Foster that the most perfect herbaceous border is one that has an old wall behind it. Mrs. Foster's book, too, is most useful in its lists of flowers that bloomed in the days of Chatucer and Shakespeare. She also devotes one chapter entirely to quotations from old poets on gardens and all the delights that spring from them. If it helps readers to know for themelves those authors, who found among the flowers of the garden apt simile; of all that is truest in human nature, she will have added a very substantial addition to the pleasure already enjoyed by those who love gardens, but yet are unfamiliar with the pages of the puets who knew well how to speak their praise." -Spectator.

"A pleasant bo:k."-Athenceum.

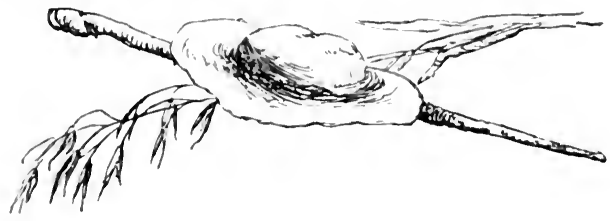




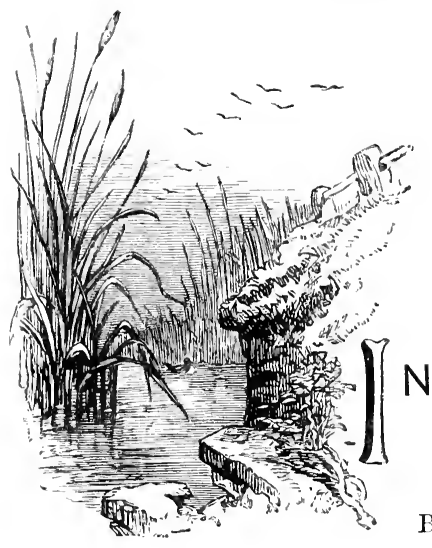

By the Rev. M. G. WATKINS, M.A.

Contents :-Devon Lane; and their Associations-At the Sea-side-Among the Heather-Up Glen Roy-Sunshine at the Land's End-Into Ballad LandOn Ottery East Hill - In Assynt-British Birds and Bird Lovers-From the Heart of the Wolds-Amongst the Sea Birds.

Crown 8ve, cloth. Price $4 s .6 d$.

\section{THE COUNTRY: ESSAYS.}

"An extremely pleasant set of essays. The writer possesses a keen love of country sights and sounds." - Athenaum.

"Nobody can take a more pleasant companion with him on his summer holidays."Academy.

"There are in these essays many historical allusions, descriptions of scenery, scientific observations, accounts of old customs and superstitions, ballads and ghost stories, all given in a cheery, chatty style."-Leeds Mercury.

"To such, papers like those of Mr. Watkins must be as glimpses of an unknown world of beauty and refreshment; a veritable recreation to the mind, and a rest to the weariness of following the ever-recurring political questions of the day. ... He brings to his subject a well-cultivated mind and a broad sympathy with the objects ronnd him. It is a treat to go "In the Country' with Mr. Watkins."-Land and Water.

"A keen observer and sincere lover of nature, the author is equally happy in his descriptions of the lanes of Devon and the wilds of Cornwall, the Scotch mountains and the Wolds of Yorkshire."-Westminster Reviezw.

"Written in a pleacant, chatty manner, in the true vein of a sportsman, a naturalist, and a scholar; and they may be recommended as furnishing a little, volume of very agreeable reading." -Ficld.

"We recommend all who have not previously made the acquaintance of the author to do so at their earliest opportunity. Mr. Watkins has s mething of the rich buoyancy of Christopher North, tinged with the quick observation of the "Gamekeeper at Home." -Notes and Queries.

"Filled with the fragrance of the heather on the hillside are the papers written by the Rev. M. G. Watkins, now published in one volume. . . . The papers are admirably written. They show that the author has a healthy mind, which can find honest employment in the country, and can, with that pleasure, mingle those other pleasures which come of wide literary knowledge. It is a very charming book." - Scotsman.

"'There are some fine touches in 'Devon Lanes and their Associations,' and 'Amongst the Heather' shows a min 1 really familiar with the mysteries of nature and the charms of country l.fe."-Tablet.

"Mr. Watkins writes with the ease and informality which should distinguish essays of this kind. . . The author has considerable antiquarian inf rmation, which he does not obtrude, however. His descriptions of nature are very good."-Lloyds Nezes. 


\section{POEMS.}

\section{By MAY PROBYN.}

Square $16 \mathrm{mo}$, cloth, gilt, $3 s .6 d$. (post free).

“"Miss Probyn's small and modest volume displays much brightness of fancy and sweetness of feeling, united with excellent metrical science. . . Perhaps we shall give the best idea of Miss Probyn's manner by quoting one of her bright and picturesque pages, taken from the quaint poem called 'Soapsuds' :-

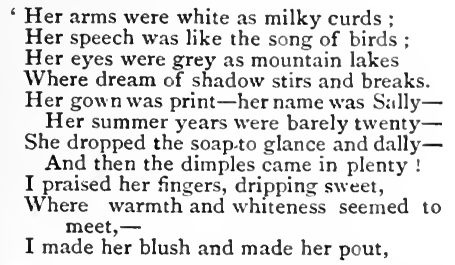

And watched her wring her linen out. $\mathrm{Oh}$, to meet her in the valley, Snatch her hand and call her Sally ! $\mathrm{Oh}$, to find her on the hill. Kiss, and call her Sally still : Oh, to clasp her quite alone, And call her Sally of cne's own ! Thyme and marjoram were sweet, All the lavender was blowingThrouzh the honeysuckled heat Bees were coming, bees were going.'

We would willingly linger longer over this charming little book, which we leave with reluctance, and with the hope of meeting its author's name once more before very l.ng." Saturday Reziez.

"Very sweet, very simple, and very skilful."-Vanity Fair.

"May Probyn has written the prettiest and daintiest volume of verse we have met with for a long time. ... She has a fresh, sweet voice, very delightful to listen to. It is nositively fascinating to read these bright, pure verses. ... Hers are exquisite fancies, tender thoughts, and a joyous delight in the beauties of colour and sound and summer; hers, too, is a sweet melancholy, the fair sorrow of love which lingers in the lines of our old English ballads. There are many of May Probyn's poems we should like to quote had we space, especially 'Soapsuds,' which is a delicious piece of wirk. She has written a volume of verse that is worth reading, some bits of which linger like perfume in the memory."-Wistminster Rerieze.

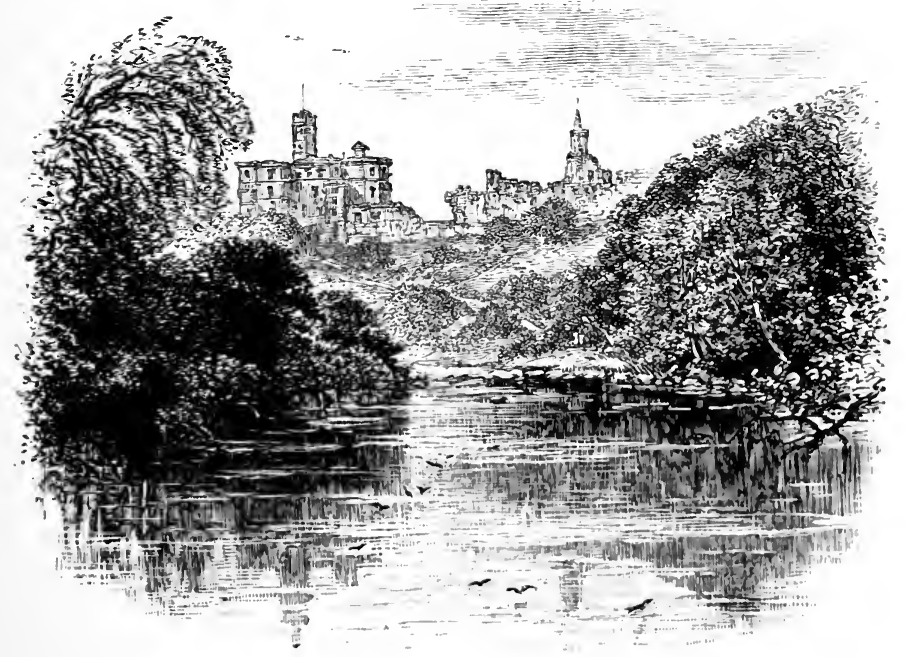




\section{A BALLAD OF THE ROAD \\ A.TD OTHER POEMS. \\ By MAY PROBYN. \\ Fcap. 8vo, cloth extra, $6 s$.}

"The author evinces fancy, thought, and some pathos. The poem which gives its name to the collection, though not the most noticeable in it, is full of spirit and has a smack of cld days. . . . The author's dexterity in the matter of rhyme is well exemplified in the "Nosegay from a French Garden,' with which the volume closes."-Athenaum.

"The 'Ballad of the Road' is a pleasant story of love and highwaymen, told with a good deal of spirit. All the book is natural and full of music. . . melodious and sweet." Academy.

"A delightful volume is Miss May Probyn's 'Ballad of the Road.' Her verse is full of dainty charm, tender pathos, and true poetic quality. There is not a trace in it of the morbid mood of self-analysis which is so common in the poetry of to-day; yet there is no lack of thought or of earnestness of tone."-Scotsmin.

"Judged by any standard which it would be fair to apply, Miss Probyn's verses are excellent. They are musical, they are interesting, there is the presence of a delicate fancy, and there is an evident appreciation of dramatic incident. . . There is considerable skill in the composition of the 'Boy Butterfly' and 'Duckie,' and they are likely to be extremely popular."-Westminster Review.

"There is much to admire in 'A Ballad of the Road, and other Poems.' The opening piece, telling of 'Sweet Mistress Ann' and the rescue of her highwayman lover, is capital. -. . The little volume gives genuine pleasure."-Graphic.

"These poems require no praise from us. There is music in every line."-Vanity Fair.

\section{TUSCAN FAIRY TALES.}

\section{Taken Down from the Mouths of the People.}

With i6 Woodclts by Edmund Evans.

\section{By VERNON LEE,}

Author of "Belcaro," “Studies in Italy," \&c.

Imperial I $6 \mathrm{mo}$, elegant cover, gilt, $3 s .6 a$.

"Sumptuously printed and prettily bound."-Athencen.

"The work will delight the little ones as well as the student. Charmingly got up and illustrated."-London Revicw.

"A thoroughly delightful book. We trust that the author may be persuaded to publish the other tales which he has collected on the same ground. If they at all resemble the present cullection, they will, we are quite sure, be heartily welcomed."-Westminster Review.

"The amount of local colouring is just sufficient to lend the old tales a new charm. The illustrations and the letterpress are printed in sepia, which has a curious, but not unpleasing, effect."-Saturday Revicev.

\section{WILL-O'-THE-WISP; \\ And other tales in Prose and Verse. \\ Crown 8 vo, 7 s. 6 d.}

"Weird and thrilling to the last degree."-Saturday Reviczu.

"Most of the pieces are of a mystical, weird, haunting, or melancholy character. . . Fancy, imagination, passion, melody, strength, and wealth of language are conspicuous in the poems included in the volume. To our thinking, the poem called "Night' is the best of the seven. The conception is exquisite and the execution masterly."-Litcrary World, December 7 th.

"The tales he has produced are, almost without exception, terrihle. . . We should not be sorry to see him again in verse, but we trust never more to have to read a collection of prose tales such as those he has given us."-Academy.

"Far above the average volumes of its kind, given to the world by men who have the love of noble thoughts and things."-Lloyd's Weekly News.

"The poem which gives title to this volume .... is a real poem, full of thought and harmoniously expressed. "Night' will, we think, be popular, so musical is it and so well designed."-Bookseller. 


\section{GODS, SAINTS, AND MEN.}

By EUGENE LEE-HAMILTON.

With ten full-page Illustrations by Exrico Mazzanti.

Crown 8vo, cloth, price $4 s .6 d$.

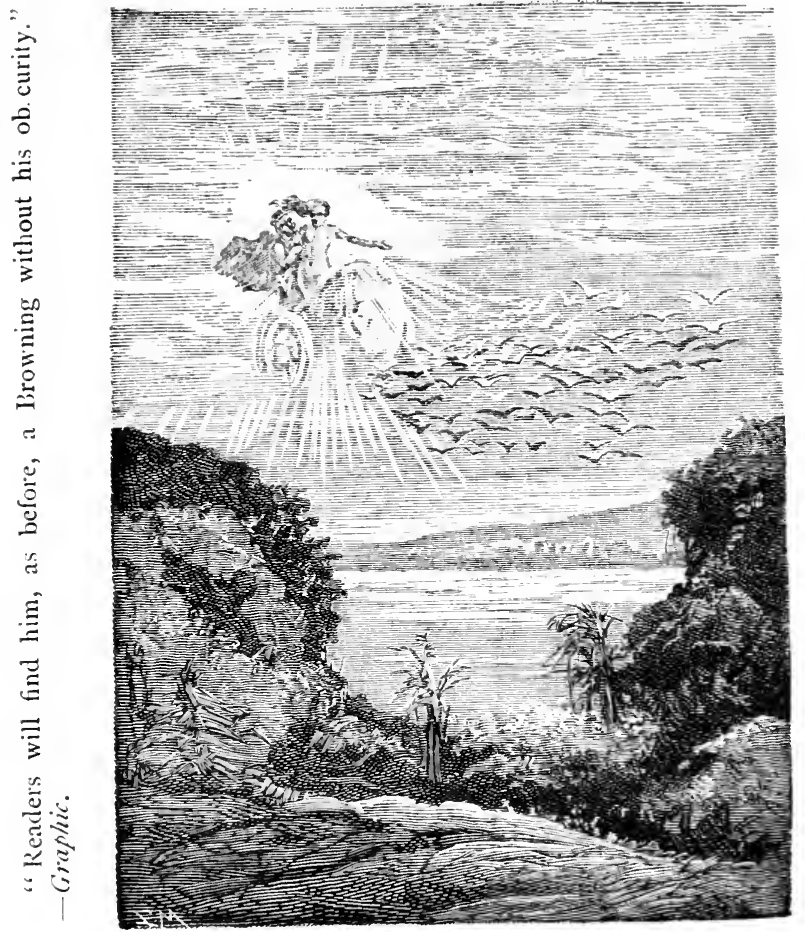

\section{MERICAS AND OTHER STORIES.}

By CLEMENTINA BLACK.

Crown 8vo, cloth, Is.; gilt, 3 s.

"We reviewed two of these stories when they appeared in the 'University' and in the 'New Quarterly' magazines. Our favourable opinion of thein is strengthened and sustained by the additions in the present volume. The title story is quaint and happily conceived. More than this, it is a delicate and gentle love tale, full of tender interest, and fraught with pretty turns of thought most charmingly expressed. The volume is one which most men will read with pleasure (for it is a mistake, which authores ses are apt to fall into, to suppose that the inferirr sex delights in the works of Ouida and Rhoda Broughton), because it is one which may he placed in the hands of their wives, sisters, and daughters without hesitation." - De'rly Mercury. 


\section{STUDIES OF \\ THE EIGHTEENTH CENTURY IN ITALY.}

By VERNON LEE.

Contents :-The Arcadian Academy-The Musical Life-Metastasio and the Opera-The Comedy of Masks-Goldoni and the Realistic ComedyCarlo Gozzi and the Venetian Fairy Comedy.

Royal 8vo, cloth, I4s.

"Mr. Vernon I,ee has written one of the most fascinating books that it has been our good fort une to meet with for a very long time. . . A singularly delightful and very able volume." - Westminster Review.

"'These 'Studies' show a wide range of knowledge of the subject, precise investigation, abundant power of illustration, and healthy enthusiasm. The style of writing is cultivated, neatly adjusted, and markedly clever ; it has a certain analogy to the style of other aesthetic writers of the day, containing (we might say by way of indication) something of Mr. Wedmore and Mrs. Pattison, with a spice of Mr. Pater, and another spice of Mr. Swinburne.

On the whole it can be cordially recommended as treating an important and little-known theme with conspicuous ability." - Athencem.

"Much detail in musical and dramatic matters may be pleasantly learned from other parts of Vernon Lee's volume."-Saturday Reviezv.

"Mr. Lee has brought to his subject a great amount of curious and recondite learning. . . . The sketch of Metastasio's life is particularly worthy of remark. Mr. Lee throws flenty of vigour and colour into his portraiture. His style has a certain robustness, while his criticism is oft $\mathrm{n}$ just and even subtle."-Spectator.

\section{BELCARO: ESSAYS ON AESTHETICS.}

\section{By VERNON LEE,}

Author of "Studies in Italy," \&c.

Contents :-The Book and its Title-The Child in the Vatican-Orpheus and Eurydice-Faustus and Helena-Chapel-Master Kreisler-CherubinoIn Umbria-Ruskinism-A Dialogue on Poetic Morality-Postscript.

\section{Crown 8 vo, cloth, $8 s$.}

"Clever and expressive, subtle and brilliant, and evincing much grasp of mind and of the subject treated. : . . The product of a remarkably acute, critical mind; it would bear to be read a second time, and would be found to repay the trouble... "Ruskinism" is an eioquent tribute to Mr. Rusk.n."-Athenaum.

"Contains some charming cssays. . . Displays in a marked degree a vividness of fancy, a wealth of imagery and illusion, and a richness of language, but does not sink into mere rhapsody or affectation. His style is picturesque, yet robust ; rich, but not luscicus." Notes and Queries.

"There is nuch in this thor ughly original and delightful book which reminds us of the essays of the eighteenth century. It is rare, indeed, to find so much thought conveyed in so easy a style; to find a writer who not only has so much that is fresh to say, but has so fresh a way of saying it. . . The way of conveying ideas is very fascinating, and has an effect of creating acovity in the reader's mind which no other mode can equal. From first to last there is a continuous and delightful stimulation of thought. The book will lead to c nversation, dreaming speculation of all kinds, of pleasant and healthy mental exercise; and it is interspersed with such perfect little sketches of sceriery and passages of so much eloquence, that it is a literary treat to read it."-Aiademi. 


\section{COMFORT IN SORROW.}

With Preface by the Rev. M. G. WATKINS, M.A.

Contains letters from celebrated persons offering consolation on deaths of children, parents, wives, husbands, and friends,

with a large gathering of elegiac verse and a selection of consolatory, reflections from divines, philosophers, and men of the world.

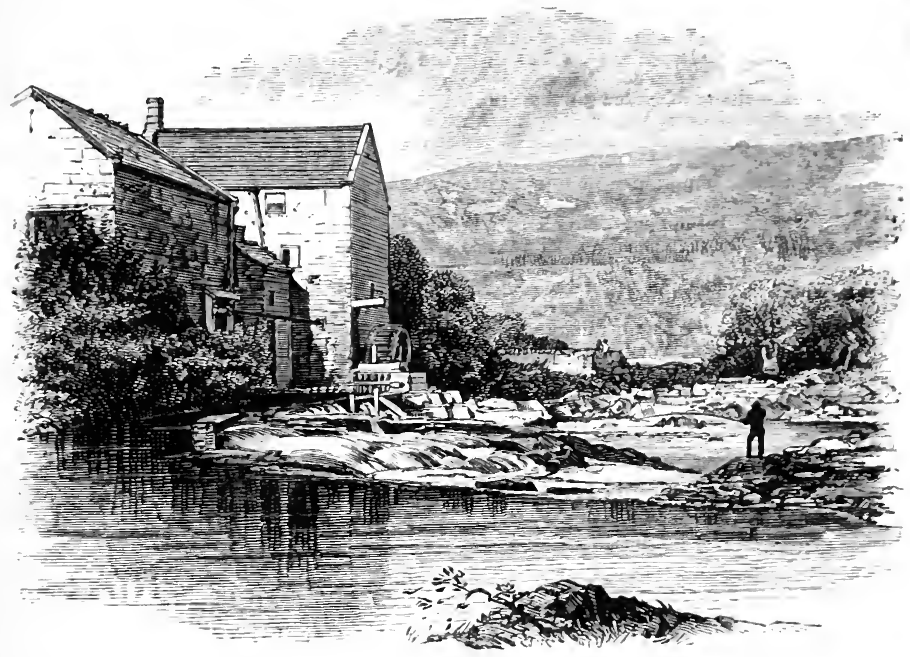

\section{ROUND A POSADA FIRE:}

A Collection of Spanish Legexds.

By Mrs. S. G. C. MIDDLEMORE.

Illustrated by Miss E. D. HALE.

(Companion volume to "Tuscan Fairy Tales.") Imp. I6mo, cloth extra. $3^{s .}$

"These are graceful stories... original and interesting. The last story, of the man in armour, is most weird." - Vanity Fair.

"Excellent stories of their kind are told by Mrs. Middlemore in her pretty volume 'Round a Posada Fire." 'The v lume has a brief Preface which . . . is bright and interesting. "The Posada del Sol, at Cuenca, is chosen as the scene in which various passengers 11 a "diligence " meet. . . They interchange stories, and each story has a certain appropriateness to the character of the person relating it, while all arc impressed with the legendary attraction of which the Preface gives us a hint. Of the actual legends it would be hardly fair to convey any notion in a brief abstract, since they are all given with a compactness which in these days of padding is specially commendable, and any further shortening could not but injure their effectivencss. . . The book is well got up and printed in clear pleasant type. . . The author may be congratulated on having produced a very readable and interesting vulume."-Saturday Roview. 
A work indispensable to the student of local and family history.

\section{THE BOOK OF BRITISH TOPOGRAPHY.}

By J. P. ANDERSON, of the Library, British Museum.

Medium 8vo, cloth, gilt top, price $25 s$.

“. 'The Book of British Topography' is of a kind which rejolces the hearts of all persons who have to do with books; the kind where a writer condescends to take a subject which he knows thoroughly, which is definitively manageable, and which, if handled properly, cannot fail to be a useful contribution, if not to literature, at any rate to the state of things which make literature possible. ...Mr. Anderson estimates the number of his entries at something like $\mathrm{I}_{4}, 000 . "-S a t u r d a y$ Reviezw.

"Few bibliographies are adapted to be more practically serviceable to an extensive public than Mr. Anderson's. . . . The extreme value of such a compilation to the topographer and antiquary will be apparent at once. . . Contains . . an immense number of minor publications which the topographical enquirer is little likely to hear of without the aid of such a catalogue as Mr. Anderson's. . . . His diligence and accuracy are beyond all praise"Illustrated London Nezes.

"The work will be of value to the student all the world over. It will enable him to discover the name of every important volume which has been published on the local history of the United Kingdom. . . We can speak with confidence of its completeness and accuracy."-Notes and Queries.

"A book of great importance to topographers and archaeologists. . . . Beautifully printed and got up."-Scotsman.

"This work appears to have been made with much skill and care, and to possess a great interest and value for collectors and librarians in the United States." - American Library Journal.

"Mr. Anderson has done a good work exceedingly well. ... Down to the present time there has been no easy method of learning what there is already in print about any place in Britain. . . . By far the best catalogue that has ever been produced." - Athenoum.

"It is not likely that very much will have to be added to this catalogue. . . A solid contribution to bibliography, arranged with admirable method."-Journal of the British Archaeological Association.

N.B.-Large paper copies, price 5os. are in request for topographical illustration. Few copies remain.

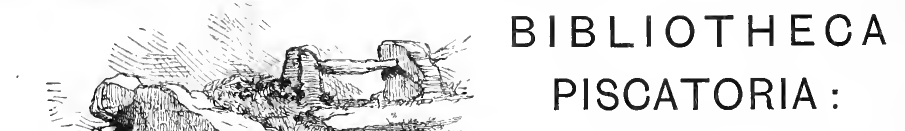

A Catalogue of Books on Angling, the Fisheries and Fish Culture, with Bibliographical Notes and an Appendix of Citations, touching on Angling and Fishing, from old English Authors.

\section{By THOMAS WESTWOOD and THOMAS SATCHELL.}

Pp. 432, medium 8vo, cloth, gilt top, price I5s.; and me lium 4 to, cloth, gilt top, price $50 s$.

"Indispensable as a conıpanion to the angler blessed (and so doubly blessed) with scholarly tastes." -Edinburgh Reviezw.

"A ' magnum opus" in every sense of the word. . . . We owe a deep debt of gratitude to the gentlemen who have given themselves so vast an amount of labour and pains to produce this almost marvellous work. . . . To say that it has been a labour of love is only to say what must be evident on every page of it. Had it not been so, the work could never have been produced."-Field. 
"Mr. Satchell has spent more than two years in ascertaining the exact titles, publishers, pagination, illustrations, and the like belonging to all the works which treat if angling, disclosed by the most careful searching. The result lies before us, a monument of diligence and good work."-Academy.

"The type has been distributed, and it will soon be as difficult to obtain as many of the rare old books it so lovingly describes."-Fishing Gazttte.

"It is something to get a full account of fish literature, and, as far as we can see, this is a full account. It is in all respects excellently done. It shows a remarkable a nount of examination and research. The authors are certainly to be congratulated upun the result of their labours."-Siotsman.

"A truly great work."-Bell's Life.

"We realise the immense labour required to complete it."-For. st and Stream.

"Admirable and most useful."-Saturday Review.

"One of the most interesting and masterful work in the whole range of bibliographical literature."-Rev. J. J. MaNLEy's Literature of Rizer and Sea Fishing.

"Anglers now possess for the first time some clear knowledge of the treasures embraced in the literature of their craft."-Athenanm.

"It was not until MIr. Satchell took up the chase (which Mr. Westwood had previously commenced) and threw his personal intelligence and zeal into the pusuit of the stray 'Waltons,' the lurking 'Secrets of Angling,' and the protean 'Mlarkhams,' that the angling-book collector could be said to have found a true 'guide, philos pher, and friend.' ... It is no mere catal gue of books-the dry details of titles, editi ns, and pages are enlivened by pleasant little ripples of bibliographical gossip, by odds and ends of angling lore, and by many a quaint and amusing extract from the rarest of the treasures now, for the first time, adequately described and properly enumerated."-Derbyshire Advertiser.

"It is certainly one of the most interesting and masterful works in the whole range of bibliographical literature. ... It may be fairly said to be as complese as it could well be made, its authors having spared neither time nor pains to perfect what has evidently been to th.em a real 'labour of love.' . . . . This will give some idea of the marvellous store of piscatory information contained in, or suggested by, the volume, which has been well and by no means hyperbolically described [in Edinburgh Re' 'iez $w$ ] as a "hagiography for the enthusiastic followers of Walton; a substantial help to the bıbliographer; a series of finger-posts by the side of English history to guide the curious student of diversions which found favour with our forefathers; an amusement for the idle angler as he notes the names of those distinguithed of old in his craft.'. . . In a word it is a litercary treasure of which not only anglers but the nation may be justly proud."-Rev. J. J. MANLEY's Literature of Sea and River Fishing (Fisheries Handbouk).

\title{
MY LIFE AS AN ANGLER.
}

\section{By WILLIAM HENDERSON,}

\author{
Author of "The Folk Lore of the Northern Counties."
}

With portrait and $\mathrm{s}_{2}$ full-page Illustrations, engraved by EDMCND EVANS.

Crown 8 vo, cloth gilt, $7 s .6 a$.

"There is no modern book about angling which could be put in the hands of either novice or veteran with greater ch.nces of charming both alike. It holds a copious store of information and anecdote, and reflects in every page its author's kind heart, ripe experience, and soundness of judgment. Like Auceps, in a book which Mr. Henderson, in comm $n$ with all anglers, must reverence, we close this delightful vulume with w.rds "I assure $\mathrm{y}^{\prime \prime} \mathrm{u}, \mathrm{Mr}$. Piscator, I now part with you full of good thoughts, not only of yourself, but your recreation.". - Athenaum.

"If our readers are not fishermen they will nevertheless find ample reward in the general matter, lively and thoughtful, with which the author has diversified his story of river-side life."-Spectator.

"A lively and picturesque collection of scattered experiences."-Saturday Fericu.

"The illustrations display a high degree of artistic merit."-F'all .Mall Gazette. 


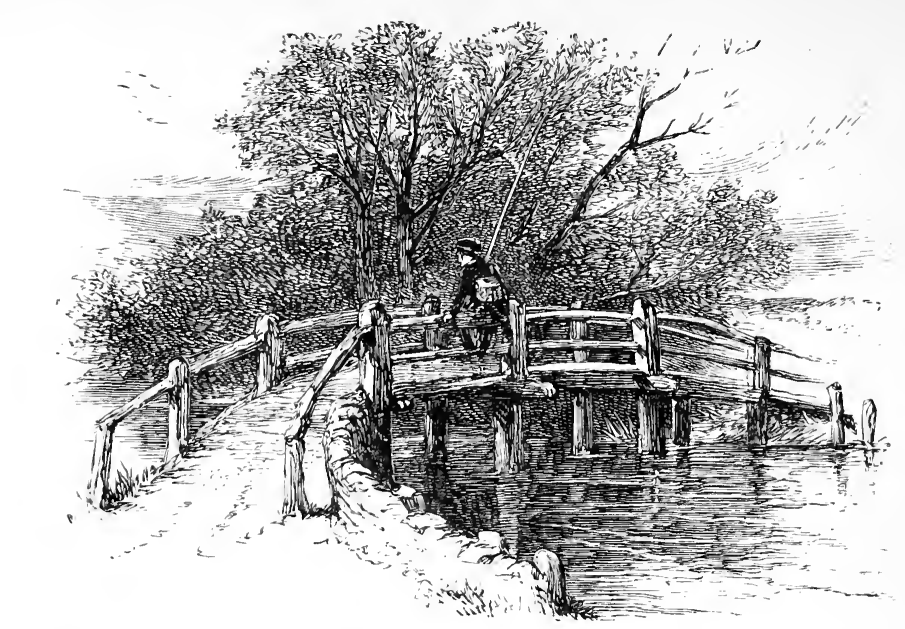

\section{TWELVE SONNETS AND AN EPILOGUE.}

\section{By T. WESTWOOD,}

In Memoriam, IzaAk WAlton, obiit I 5 th Dec., i683.

4to, cloth gilt, $7 s .6 \%$

100 copies finely printed in red and black at the Chiswick Press. Chiefly for presentation.

" Both the publisher and author of the Twelve Sonnets in commemoration of Izaak Walton's bi-centenary, honour that charming writer in worthy fashion. . . . They are appropriately subdued in style, and felicitous in language. The reverential sentiment of all book-lovers and good anglers is excellently expressed in Mr. Westwood's Epilogue."-Saturday Revieze.

"A really admirable c)llection of sonnets. . . . The first is to Thomas Satchell "friend, fellow worker'.... and these fellow workers have assuredly a fame that will be enduring."-Field.

"A marvel of luxury is this dainty volume of sonnets . . . graceful and flowing, free from fl orid rhetoric, gravely harmonious, as if in sympathy with the simple, kindly, reflective spirit of the man in whose bonour they are written."-Whitehall Review.

"Mr. Westwood, the angler poet of the Igth century, who more than any other writer has crught the spirit of Walton .... has never commemorated the angling patriarch more gracefully than in these sonnet.s. The Epilogue . . . will at once go straight to our hearts." -Acatemy.

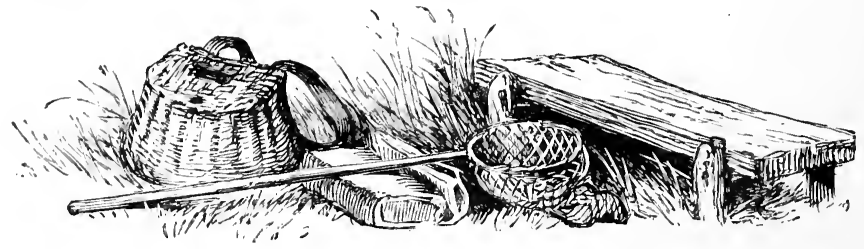


" This series of reprints is under the care and direction of Mr. Thcmas Satchell, and it is a pleasure, indeed, to handle our old favourites in the r new attire, feeling sure the while that no unwarrantable libertics have been taken with the text, and that the editorial work has been discreetly as well as skilfully performed."-Exeter Gazette.

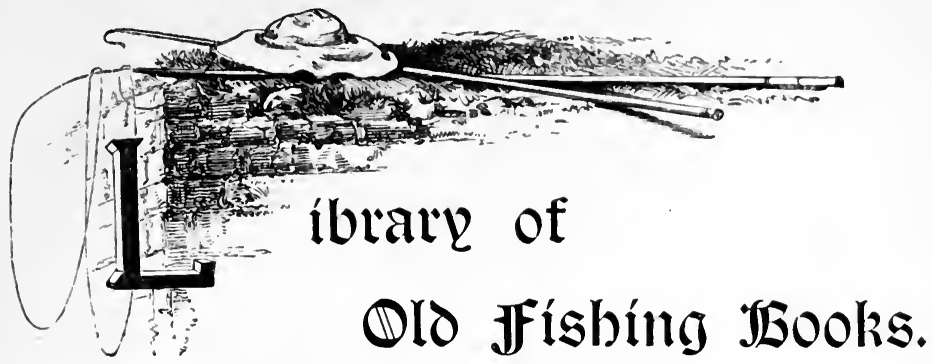

A collection designed for the use of the "scholarly fisherman," and consisting chiefly of reprints of works of unusual

interest or extreme rarity, carefully edited, well printed

in quarto form on the best hand-made foolscap paper, and issued in a permanent half-leather binding, Roxburghe style, with gilt top and rough edges.

The following have been already issuct.

Fcap. 4to, half-morocco, price sos. 6.t.

\section{THE CHRONICLE OF THE COMPLEAT ANGLER}

\section{OF IzaAi Walton and Chari.es CotTox.}

\section{By THOMAS WESTWOON.}

A New Edition, greatly enlarged by the author, with some Nctes and Additions by Thomas Satchel.t.

"There is no living writer who can approach Mr. Westwood in his particular sphere. A subtle influence pervades his writings which brings him into personal relations with his readers, Perhaps his secret of winning sympathy lies in his evenness of thought, his purity of diction, and his quiet, peaceful tone; qualities which render him a worthy exponent of one of the most beautiful pastorals in the English language."-Excter Gaze'tte.

"It is not necessary at this time of day to express the praise that might be written of Mr. Westwood's style, the 'Chronicle' being almost as much a pastoral as the 'Compleat Angler." "-Field.

"A gossiping essay on the various editions of the brightest book in angling literature, executed with the frankness of a brcther of the pleasant craft, the perception if an artist. the feeling of a poet, the tone of a gentleman, and the allusions and illustrations that bespeak the scholar."-Athaneum.

"Entertaining as well as instructive."-Satuday Revicu".

"Mr. Westwood has made, out of a subject apparently unpromising, an escay w'tich s especially marked by its curiosa felicitas." - Spectator. 


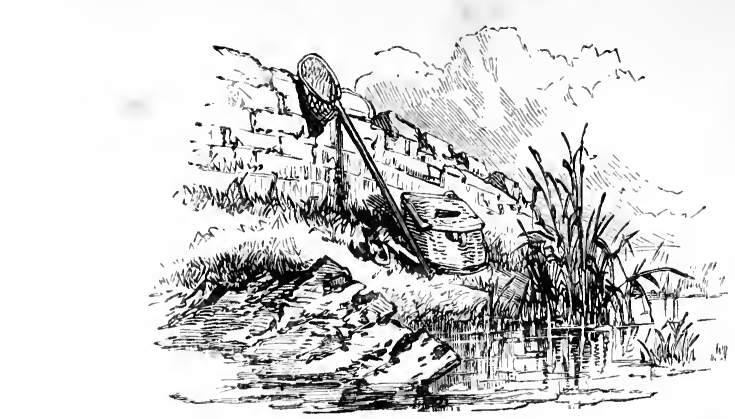

THE SECRETS OF ANGLING (1613).

By J [OHN] D[ENNYS].

With an Introduction by T. Westwood.

Fcap. 4to, half-morocco, $7 s .6 d$.

"We congratulate Mr. Westwood on his charming reproduction of this old and rare angling poem.... Beloe said of it that "perhaps there does not exist in the circle of English literature a rarer book than this.' Indeed, Sir John Hawkins confessed he could never get a sight of it. . . Anglers will now be able to read this poem as it was presented to the world."-Notes and Queries.

"Mr. Westwood, angler and poet himself, was the proper person to reveal the greatest of angling poets. ...J. J. D.'s verses are earnest and impassioned, dainty, harmonious, and polished. . . . All 'brothers of the angle' will gratefully accept th.s beautiful reprint of a book which, on account of its rarity, has been practically unknown to all save a few bookworms."-Athenceum.

"Where is our debt of gratitude to Mr. Satchell to end? The 'Bibliotheca Piscatoria' was a thing to be thankful for ; and now the 'Secrets of Anglng'-we can only again express. our gratitude for the boon" -Field.

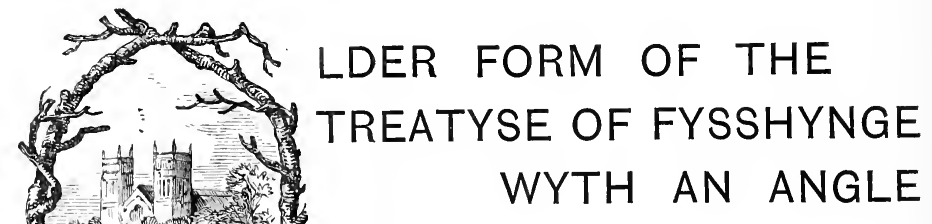

(c. I450) now first printed from a Manuscript in the collection of Mr. Denison, with preface and Glossary by Thomas Satchell.

Price $7 s .6 d .200$ copies pinted.

“'The only known manuscript of the 'Treatyse of Fysshyng,' formerly in the possession of Mr. William Herbert, afterwards of Mr. Joseph Haslewood, and now in the famous Denison collection, has been examined by Mr. Satchell, who finds it to contain an independent text of a date not later than 1450 . It is drawn from the same, original as that printed in 1496 , but instead of the 'readings between it and the printed copy' being as stated in the preface to Mr. Pickering's reprint 1827 , 'very few and unimportant,' it varies the phrase throughout, and in many places alters the sense, besides containing many short passages not included in the printed version."-A theneunn.

"Transcribed and edited with all the patient, conscientious skill for the exercise of which Mr. Satchell is famous."-Exeter Gazette. 


\section{A BOOKE OF FISHING WITH HOOKE AND LINE,}

AND OF ALL OTHER INSTRUMENTS THEREUNTO BELONGING. . . MADE BY L[EONARD] M[ASCALL], I 590.

With Preface by Thomas SAtchell. 12 Woodcuts, Fcap, 4to, half-morocco. Price $75.6 d$.

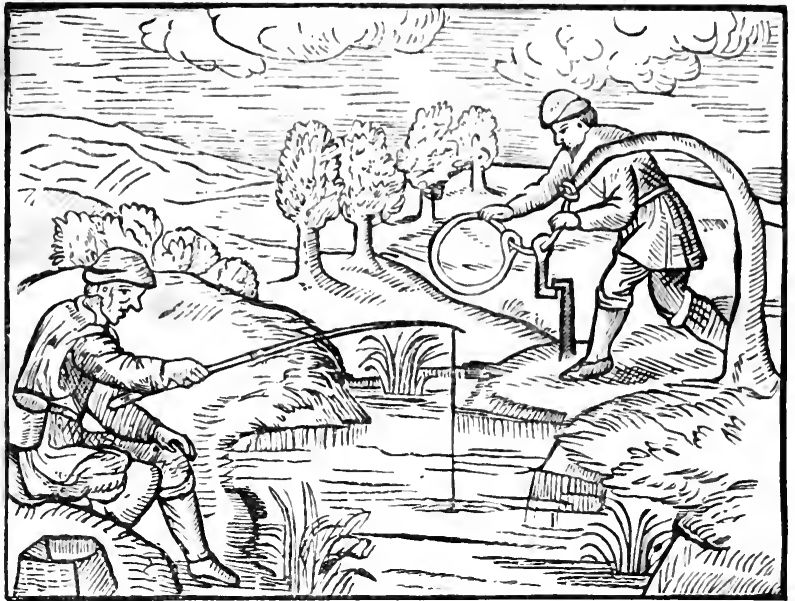

The Library will also include:-

MARKHAM'S “PLEASURES OF PRINCES” (I6I4), GRYNDALL'S “BRIEFE TREATIS OF FISHING” ( 1596 ), "A IEIVELL FOR GENTRIE" (I6I4),

"THE GEOPONIKA OF CASSIANUS BASSUS" (c. 960). And other Works which are one and all unattainable by the Collector.

“A very charming volume."-Professor G. BRown GoodE, U. S. Fisheries Commissioner. Fcap. 4to, cloth, gilt. Price 6s.

\section{THE ANGLER'S NOTE-BOOK AND NATURALIST'S RECORD.}

A Repertory OF FACT, INOUIRY, AND DISCUSSION ON Field-SPORTS AND subjects of Natural History.

With six illustrations on plate paper. The GREex Series Complete.

Contents :- The Oldest English Treatice on Fishing, and Anglo-Saxon Fish-Names, by the Rev. Professor Skeat-An Unknown Angling Poet-One of the Mysteries of Angling Literature-Conrad Heresbach-Concerning Fishing (a Translation of his DE Piscatione), dec., by Thomas WestwoodFishing Cats, \&ic., by William IIenderson-Invitation to Coquet, by Joseph Crawhall, editir of "Newcastle Fishers' Garlands"-Fishing a Scotch Loch, by the Rev. M. ( $x$. Watkins-Notes from the Journals of Jonathan Couchand several hundred papers and short notes-in prose and verse-by many other well-known writers and naturalists.

N.B. - Very few copies remain, the stock having been destroy'ed by a fire at the binder's. 


\title{
THE ANGLER'S NOTE-BOOK.
}

\section{NEW SERIES TO BE COMPLETED IN TWELVE NUMBERS}

Fcap. 4to. Price $6 s$. on stout paper, and I2s. on hand-made paper, with Illustrations.

Complete and post-free to subscribers only.

\section{Conducted by the Editors of the "Bibliotheca Piscatoria."}

Free Copies will be sent to all Persons desiring theme, but single numbers will not be sold

"Promises to be as interesting as its predecessor, and does credit to its enthusiastic editors." - Athenceum.

"The most scholarly and interesting publication on angling ever published."-The Nation (of New York).

Office: 6, DUKE STREET, ADE.LPHI, W.C.

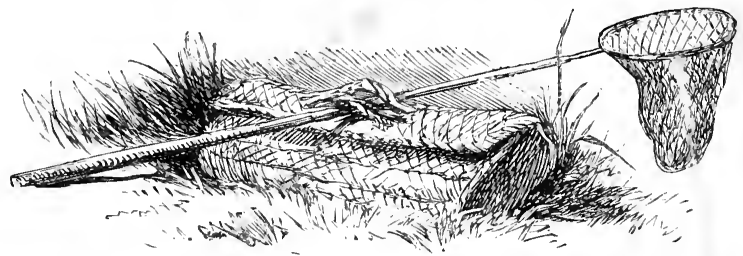

"One of the most elegant books pertaining to the art ever produced."-Once a Week.

\section{A QUAINT TREATISE ON FLEES}

\author{
AND
}

\section{THE ART A' ARTYFICHALL FLEE MAKING.}

By an Old Man well known on the Derbyshire streams a century ago ; printed from an old MS. never before published;

the original spelling and language being retained, with Editorial Notes. Patterns of Flies, and Samples of the Materials for making each Fly.

$$
\text { By W. H. ALDAM. }
$$

With Two Facsimiles of Water-colour Drawings by JAues Poole, Esq. Imp. $4^{\star}$,

\section{In handsome cloth cover. Price $\ell_{4} 4 s$.}

" None but a perfect enthusiast could have conceived and carried out so remarkable a work as this. Since Dame Juliana Berners wrote her 'Treatyse of Fyshing wyth an Angle,' no work so remarkable has issued from the press upon this subject. . . . The illustrations are . . the actual flies themselves, dressed by Mr. Aldam himself and 'by two of the most accomplished fly-tyers in the kingdom.' . . Every two or three pages or so, in this book. there is a thick cardboard page, in which are two counter-sunk oval medallions: and here you have, first the fly, below it the silk it is tied with, and the harl, floss, or dubbing for the body ; on one side is the feather from which the wings are maie; on the other, the hackle for the legs."-Field.

"No verbal description can convey the idea of shades of colour; but the student of flymaking has the colours and materials themselves before him."-Times.

"Fly-fishers will be delighted with this book."-Standard.

"Those who are fond of fly-fishing should obtain a copy of this handsome and most useful work, which is not only interesting to anglers, but also to the public in general who admire perseverance, taste, and first-class workmanship."-FRANK BUCKLAND.

Applications for copies must be made at the office of "The Angler's Note-book."

LONDON: R. CLAY, SONS, AND TAYLOR, PRINTERS. 
1 



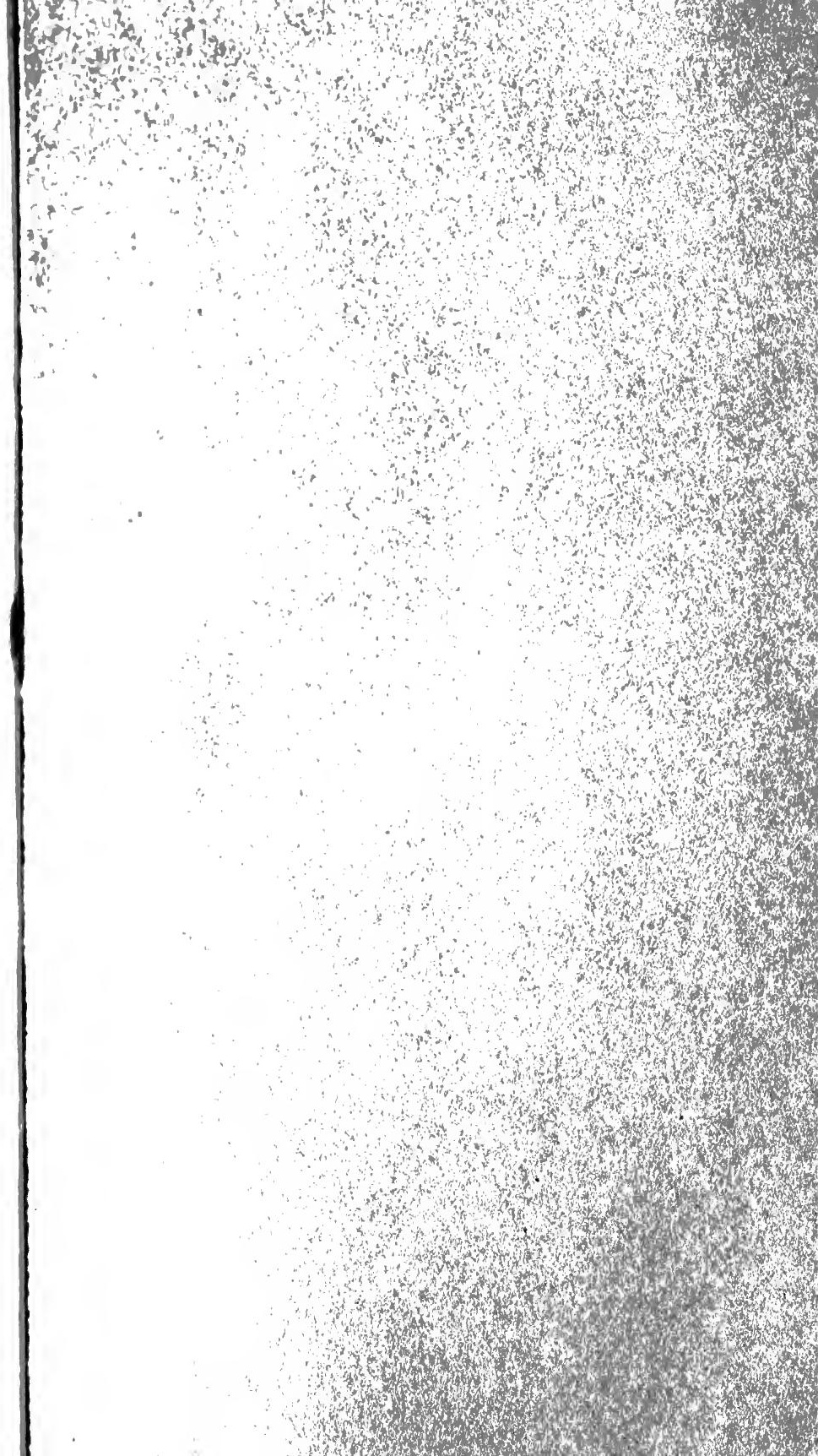




\section{FOURTEEN DAY USE}

RETURN TO DESK FROM WHICH BORROWED

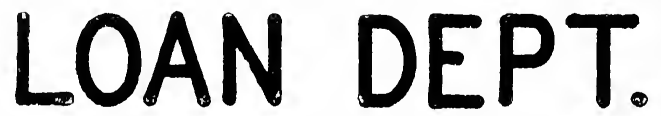

This book is due on the last date stamped below, or on the date to which renewed.

Renewed books are subject to immediate recall.

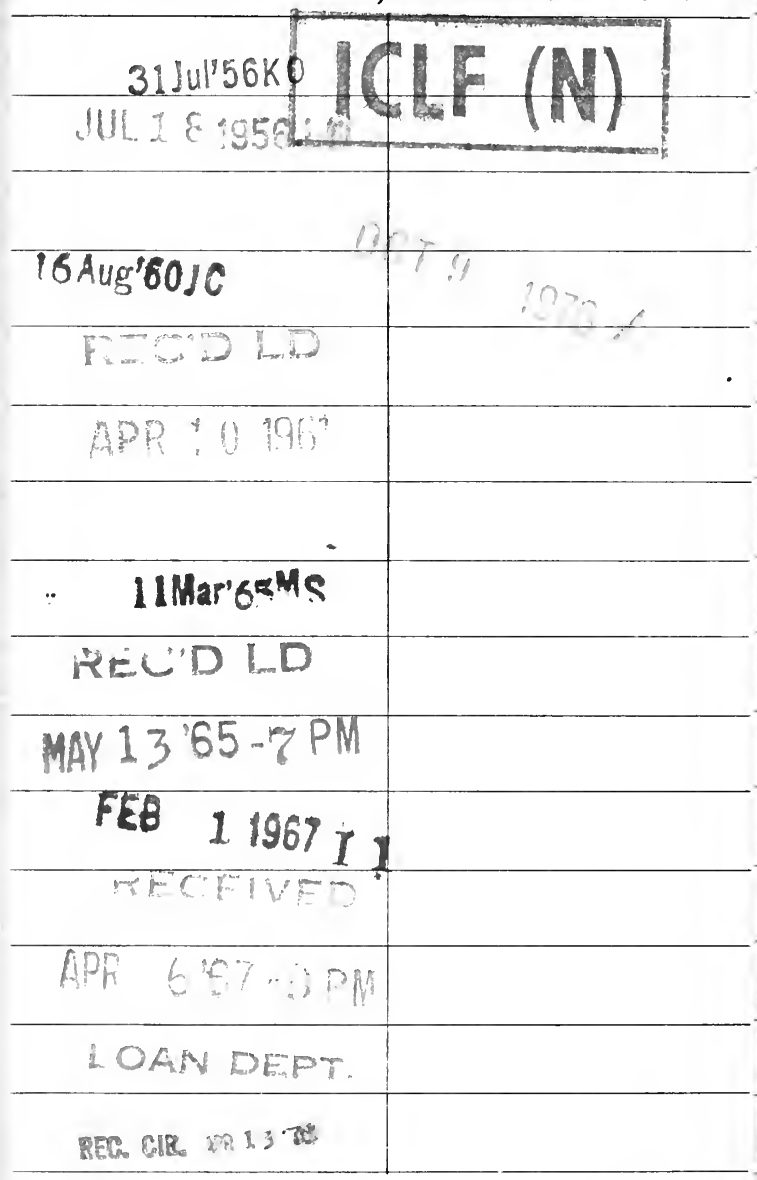


YB 06606́ 9.79 
